Journal of Natural History, 1999, 33, 1487-1512

\title{
A revision of the genus Platythelphusa A. Milne-Edwards, 1887 from Lake Tanganyika, East Africa (Decapoda: Potamoidea: Platythelphusidae)
}

\author{
N. CUMBERLIDGE $\dagger$, R. VON STERNBERG $\ddagger$, I. R. BILLS§ and \\ H. MARTIN $\dagger$ \\ $\dagger$ Department of Biology, Northern Michigan University, Marquette, \\ Michigan 49855, USA \\ $\ddagger$ Centro di Ecologia, Instituto Venezolano de Investigaciones Cientificas \\ (IVIC), Caracas, Venezuela \\ $\S J$. B. L. Smith Institute of Ichthyology, Grahamstown, South Africa
}

\begin{abstract}
The genus Platythelphusa is revised and six species are recognized. These species are $P$. armata A. Milne-Edwards, 1887, $P$. maculata (Cunnington, 1899), $P$. conculata Cunnington, 1907, P. tuberculata Capart, 1952, P. polita Capart, 1952 and $P$. echinata Capart, 1952. A seventh taxon, P. denticulata Capart, 1952 is considered here to be a junior synonym of $P$. conculata. A diagnosis for each species is provided and most are figured from the type. Keys to the families of African freshwater crabs and to the genus Platythelphusa are also provided.
\end{abstract}

Keywords: Crustacea, Brachyura, Potamoidea, freshwater crab, Platythelphusa, identification key, taxonomy, Lake Tanganyika.

\section{Introduction}

This study focuses on the taxonomy of the endemic species of freshwater crabs found in Lake Tanganyika, East Africa. This lake lies on the floor of the Western Rift Valley and is over $650 \mathrm{~km}$ long, up to $50 \mathrm{~km}$ wide, and over $1000 \mathrm{~m}$ deep in places. Lake Tanganyika is the oldest of the East African great lakes and is estimated to be over 7 million years old, but aspects of the geological history and of the origin of the lake's fauna are still somewhat uncertain (Beadle, 1981). Lake Tanganyika lies within the boundaries of four countries: the Democratic Republic of the Congo (formerly Zaire), Burundi, Tanzania and Zambia. The fauna of Lake Tanganyika in general includes large numbers of endemic species; this not only reflects the wide ecological diversity of this tropical lake, it also reflects its great age and long period of past isolation (Coulter, 1991).

While the cichlid fish in the lake have been well studied (see Brichard, 1989 and the review by Coulter, 1991), little work has been done on the lake's endemic species of freshwater crabs, despite their economic, ecological and evolutionary importance. The number of species of the endemic genus Platythelphusa A. Milne-Edwards, 1887 varies according to taxonomic authority. Cunnington (1920) recognized three species, Bott (1955) recognized one species, and Capart (1952) and the present work each recognize six species (but differ in which are valid). Coulter (1991) listed seven 
species of Platythelphusa by simply combining the opinions of Bott (1955) and Capart (1952).

The increasing interest in the biological resources of Lake Tanganyika increases the need for a revision of the platythelphusids. It is currently difficult to identify crabs from Lake Tanganyika because the identification key of Bott (1955) does not include all described species and because Capart (1952) and Coulter (1991) did not provide keys.

It is important to be able to make precise identifications of African freshwater crabs, not only because some of the larger species found in Lake Tanganyika (e.g. $P$. armata) support small commercial fisheries, but also because some of the smaller species of crabs are preyed upon by commercially important species of fish. However, at present it is difficult for the non-specialist to distinguish between species of Platythelphusa (especially some of the small species that live inside empty snail shells). The present work aims to revise the taxonomy of this group by focusing on important taxonomic characters such as those of the gonopods, mouthparts, pereiopods and sternum (Cumberlidge, 1999). In most species of Platythelphusa these characters were previously undescribed and this lack has contributed to the taxonomic uncertainty surrounding this group. For these reasons a revision of Platythelphusa that takes into account the modernization of the discipline, and which updates the identification keys to species, genera and families is long overdue.

\section{Material}

All relevant type material has been examined, and each species has been redescribed either from the type material, or (in the case of $P$. tuberculata) from additional adult male specimens. The study was prompted by the examination by one author (NC) of more than 230 new specimens of freshwater crabs from Lake Tanganyika. These were collected between February 1992 and June 1993 from 16 different localities in Lake Tanganyika, mostly from Burundi (in the northeast) and Zambia (in the southwest). This collection was made by one author (IRB) as part of the Central African Waters project (CAW), a research initiative aimed at surveying the fish and invertebrates of the African great lakes, including Lake Tanganyika. The new material contained representatives of all six species in the genus Platythelphusa as well as the three species of Potamonautes MacLeay, 1838 (Potamonautidae Bott, 1970) reported to be associated with Lake Tanganyika (Potamonautes lirrangensis Rathbun, 1904, P. platynotus Cunnington, 1907 and P. loveridgei Rathbun, 1933; Capart, 1952; Bott, 1955). Many of these specimens were in superior condition to the type specimens which were used by A. Milne-Edwards (1887), Cunnington (1899, 1907, 1920) and Capart (1952) to prepare the original descriptions of the species found in the lake. Direct comparisons were made between these new specimens and the relevant type material.

Maturity in female specimens was based on the examination of the degree of development of the abdomen. In adult female freshwater crabs the telson of the abdomen is wide enough to reach the coxae of the chelipeds and the entire abdomen completely covers the sternum (Cumberlidge, 1999). This permits the separation of adult females from juveniles and subadults, and allows an estimate of the moult of puberty for the species (table 2). Since male and female freshwater crabs of the same species grow at similar rates and reach a comparable range of body sizes as adults, this measurement also allows an estimate of the stage of development of male crabs. 


\section{Abbreviations}

$\mathrm{CAW}=$ Central African Waters project; $\mathrm{MRAC}=$ Muséum Royal d'Afrique Centrale, Tervuren, Belgium; NHML = Natural History Museum, London; ZMB = Museum für Naturkunde der Humboldt-Universität, Berlin, Germany; $\mathrm{cw}=$ distance across the carapace at widest point; $\mathrm{cl}=$ carapace length measured along median line, from anterior to posterior margin; $\mathrm{ch}=$ carapace height, maximum height of cephalothorax; $\mathrm{fw}=$ front width, width of front measured along anterior margin; $s=$ thoracic sternite; e=episternite; $s 4 / 5, s 5 / 6, s 6 / 7, s 7 / 8=$ sternal sutures between adjacent sternites; s4/e4, s5/e5, s6/e6, s7/e 7=episternal sutures between adjacent sternites and episternites; $\mathrm{a} 1-\mathrm{a} 7=$ abdominal segments $1-7 ; \mathrm{P} 1-\mathrm{P} 5=$ pereiopods $1-5$; coll. $=$ collected by $\mathrm{m}=$ male; $\mathrm{f}=$ female; $r=$ correlation coefficient; don. $=$ donated by; ad. $=$ adult; subad. $=$ subadult; juv. $=$ juvenile. All measurements are given in mm.

\section{Systematic account}

Family PLATYTHELPHUSIDAE Colosi, 1920

Platythelphusinae Colosi, 1920: 9.

Type genus. Platythelphusa A. Milne-Edwards, 1887.

Diagnosis. Carapace outline subhexagonal, rounded; frontal margin lined by small teeth or distinct granules, anterior margin of front projecting straight out or only slightly deflexed; external angles of front either marked by sharp spines or by small granules; stout triangular process (which may be produced into a small tooth, the descending frontal tooth) beneath external angles of front descending into orbital hiatus; anterolateral margin of carapace behind exorbital angle with between two to four large forward-directed pointed teeth. Suborbital margin lined by small teeth or small granules, medial end marked by distinct spine or small tooth. Postfrontal crest distinct but always incomplete and never meeting the anterolateral margins; mid-groove on postfrontal crest short. Anterolateral margin always lacking an intermediate tooth between exorbital angle and epibranchial tooth.

Description. Fields of short carinae in lateral regions of carapace; anterolateral margin of carapace continuous with posterolateral margin. Suborbital margin lined by small teeth or small granules, medial end marked by distinct spine or small tooth; occlusal (sub-ocular) tooth in orbital hiatus well developed. First antennal segment oval and fused into epistome; basal antennal segment large and rectangular, with large transverse process in most species, lying in orbital hiatus between descending frontal tooth and occlusal tooth; next antennal segment robust and rectangular, supporting short antennal flagellum. Relative carapace width (cw/fw), relative carapace length $(\mathrm{cl} / \mathrm{fw})$ increase allometrically as crabs grow, but relative carapace height grows isometrically, (ch/fw) proportionally same in both juveniles and adults.

Distinct endostomial ridges marking medial side of left and right anterior respiratory channels; epistomial triangle conspicuous, pointing horizontally. Mandibular palp with three segments, first two segments of palp incompletely fused so that sulcus between segments still visible under magnification; terminal segment a single large oval process positioned behind mandible; no additional (anterior) lobe of any kind. Third maxillipeds filling entire buccal frame, except for transversely oval anterior respiratory openings at superior lateral corners; merus of third maxilliped with flanged edges and conspicuously widened upper lateral margins; ischium of third maxilliped same width as merus; ischium of third maxilliped always lacking 
longitudinal groove, suture between ischium and basis marked by distinct line. Inferior lateral corner of ischium of third maxilliped produced into distinct, characteristic short basal process overlapping base of exopod of third maxilliped; exopod of third maxilliped long, robust, reaching two thirds of way along merus; distinct medial process on distal end of exopod; exopod always with long flagellum.

Adult male chelipeds distinctly unequal (i.e. heterochelous); major cheliped (usually right) both longer and higher. Dactylus of major cheliped of adult males typically very robust, arched or highly arched, with enlarged teeth on major cheliped. Medial margin of carpus of cheliped with two long pointed teeth (first and second carpal teeth); all species with third carpal tooth (articular tooth) between carpus and propodus. Merus of cheliped triangular in cross section with three sides or surfaces: anterior (medial or inner) surface, posterior (lateral or outer) surface and inferior (ventral) surface. Medial margin of inferior surface of merus of cheliped with single large pointed distal tooth; superior margin of merus of P1 (where anterior and posterior surfaces meet) with rows of prominent, rough grains. Smooth oval surface (meral tympanum) on inner side of merus of cheliped.

P5 always shortest of walking legs (P2-P5); merus triangular in cross section. Dactyli of P2-P5 tapering to a point, with four rows of downward-pointing sharp corneous spines; dactylus of P4 long, dactylus of P5 very short (shortest segment of all walking legs).

Sternal suture $\mathrm{s} 1 / \mathrm{s} 2$ short but complete and visible; sternal suture $\mathrm{s} 2 / \mathrm{s} 3$ complete, crossing entire sternum; sternal suture $s 3 / s 4$ incomplete, reduced to two small notches at sides of sternum. Episternal sutures e4/s4, e5/s5, e6/s6 and e7/s7 all complete, visible in all species. Within sterno-abdominal cavity two of four posterior sternal sulci (s4/s5, s5/s6) widely separated medially, while $s 6 / \mathrm{s} 7, \mathrm{~s} 7 / \mathrm{s} 8$ almost continuous but not quite meeting in midline, so that vertical sulcus (median line) broad and interrupted in middle by diamond-shaped space. Pair of small rounded sternal condyles (bouton pressions) within sterno-abdominal cavity on sternite s5; penis meeting $\mathrm{s} 8$ in mid-point of lateral margin. Male sexual openings on coxae of P5, female sexuál openings in sterno-abdominal cavity on sternite s6 (i.e. members of this family belong to the Heterotremata sensu Guinot, 1977).

Gonopod 1 and gonopod 2 each with four distinct parts (Cumberlidge, 1999). Subterminal segment of gonopod 1 always longer than terminal article of gonopod 1 ; subterminal segment usually reaching as far as $\mathbf{s} 5 / \mathrm{s} 6$. Subterminal segment of gonopod 1 typically a simple rectangle (longer than wide); in some species broadened in mid section and at base; ventral side of subterminal segment of gonopod 1 not completely enclosed: medial side exposed, while lateral side covered by long lateral flap folded inwards across segment from lateral margin; lateral flap reaching at least halfway across segment but never all the way across; margin of lateral flap edged lengthways by short bristles and hairs; margin continuous with longitudinal groove of terminal article of gonopod 1.

Ventral side of terminal article of gonopod 1 with two folds and a longitudinal groove. Dorsal side of terminal article of gonopod 1 smooth; distinct membrane (dorsal membrane) at junction between the two distal segments of gonopod 1 . Terminal article of gonopod 1 relatively short, about one-quarter to one-fifth length of subterminal segment of gonopod 1; terminal segment angled outward between $45^{\circ}$ and $90^{\circ}$ to the vertical; terminal article of gonopod 1 with two lengthways folds (medial and lateral folds) separated by longitudinal groove. Medial and lateral folds 
on terminal article of gonopod 1 equal. Terminal article of gonopod 1 short, coneshaped, tapering strongly to pointed or tubular tip, with terminal hole (apical opening). Tip of terminal article of gonopod 1 of adult males reaching to 55 (a little further than sternal condyles on s5). Gonopod 2 a little longer than gonopod 1. Subterminal segment of gonopod 2 long, always same length as subterminal segment of gonopod 1. Subterminal segment of gonopod 2 widest at base, tapering sharply inward to form long, thin, rod-like process which supports terminal segment; rounded cup or collar at junction between terminal article and subterminal segment of gonopod 2. Terminal article of gonopod 2 is a flagellum measuring about one half as long as subterminal segment of gonopod 2. Male abdomen slim; triangular outline formed by abdominal segments a3-a7; telson of male abdomen (a7) triangular; a1-a6 four-sided; a3 broadest segment; sides of a4-a7 angled inward; outline of female abdomen broad and shield-shaped, telson forming broad triangle.

Remarks. This family contains only one genus, Platythelphusa. The closest relatives of the Platythelphusidae are probably the Potamonautidae and the Potamidae with which they share a similar gonopod and male abdomen.

Key to the African families of freshwater crabs

la Mandibular palp 3-segmented . . . . . . . . . . . . . . . . . . . . . 3

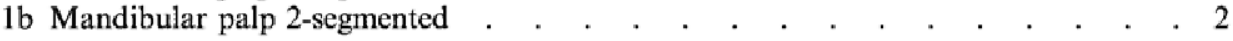

2a Antennules folding almost vertically; anterior respiratory openings elongate, tubiform chimney-like funnels formed by endopods of first maxillipeds and lateral surfaces of endostomes; male abdomen with only six visible segments (abdominal segment 1 completely concealed by posterior carapace). . . . . . . . . Deckeniidae

2b Antennules folding horizontally; anterior respiratory openings simple holes; male abdomen with seven visible segments (abdominal segment 1 clearly visible) .

3a Carapace outline subhexagonal, rounded; frontal margin lined by small teeth or distinct granules, anterior margin of front projecting straight out or only slightly deflexed; external angles of front either marked by sharp spines or by small granules; stout trfangular process (which may be produced into a small tooth) beneath external angles of front descending into orbital hiatus. Suborbital margin lined by small teeth or small granules, medial end marked by distinct spine or small tooth.

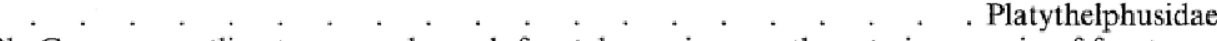

3b Carapace outline transversely oval; frontal margin smooth, anterior margin of front distinctly deflexed; external angles of front smooth, lacking spines or granules; lacking stout triangular process beneath external angles descending into orbital hiatus. Suborbital margin smooth, lacking spine or tooth at medial end. . . . Potamidae

Platythelphusa A. Milne-Edwards, 1887

Platythelphusa A. Milne-Edwards, 1887: 146; Hilgendorf, 1898: 21; Moore, 1903: 286; Rathbun, 1905: 268; Cunnington, 1907: 266-268; Alcock, 1910: 253-261; Colosi, 1920: 9-10; Cunnington, 1920: 557; Balss, 1936: 196; Chace, 1942: 224.

Limnothelphusa Cunnington, 1899: 698; Moore, 1903: 280; Rathbun, 1905: 269.

Hydrothelphusa (Platythelphusa): Bouvier, 1917a: 615-621, 1917b: 657-659, 1921: 41.

Potamonautes (Platythelphusa): Bott, 1955: 226; Coulter, 1991: 253-257.

Type species. Platythelphusa armata A. Milne-Edwards, 1887, by monotypy.

Diagnosis. As for family.

Remarks. The present work recognizes six species of Platythelphusa: $P$. armata A. Milne-Edwards, 1887, P. maculata (Cunnington, 1899), $P$. conculata Cunnington, 1907, P. tuberculata Capart, 1952, P. polita Capart, 1952 and P. echinata Capart, 
1952. Five of these species were recognized by Capart (1952) who included $P$. denticulata Capart, 1952 and excluded $P$. conculata following his examination of the type of $P$. conculata which he judged to belong to either $P$. maculata or to $P$. armata.

Bott (1955) referred all taxa of Platythelphusa to the family Potamidae Ortmann, 1896 (as Potamonidae) in the genus Potamonautes subgenus (Platythelphusa). Bott (1955) recognized only one species: Potamonautes (Platythelphusa) armata and treated $P$. maculata as a junior synonym, and $P$. conculata as a subspecies. However, Bott (1955) overlooked the significant work of Capart (1952) which reported on six species of Platythelphusa from the lake, four of them new to science. Bott (1955) therefore dealt with only three taxa, $P$. armata, $P$. maculata and $P$. conculata, and assigned them all to a single species, Potamonautes (Platythelphusa) armata. Later Bott (1970) transferred these taxa to the Potamonautidae.

Cunnington (1920) and Capart (1952) recognized Platythelphusa as a distinct genus, and placed other species found in Lake Tanganyika (now assigned to Potamonautes) in the genus Potamon. Capart (1952) recognized P. armata and $P$. maculata as valid species and described four new species ( $P$. denticulata, $P$. echinata, $P$. polita and $P$. tuberculata). However, that author expressed uncertainty about the validity of two species ( $P$. conculata and $P$. denticulata) which he thought may actually be juvenile forms of described species. The results of the present study generally support Capart's (1952) conclusion that Platythelphusa is a valid genus with six species. The main difference is that $P$. conculata is regarded here as a valid species and $P$. denticulata is considered here to be a junior synonym of $P$. conculata.

Capart (1952) included Platythelphusa in the family Potamonidae Ortmann, 1896, which was later emended to the Potamidae (Opinion 712, Bull. Zool. Nomenclature, 21, 1964). Bott (1955) originally assigned Potamonautes (Platythelphusa) to the Potamonidae (= Potamidae); later, Bott (1970) transferred this genus to the Potamonautidae Bott, 1970, and this arrangement was accepted by Coulter (1991). Cumberlidge (1999) raised the monotypic subfamily Platythelphusinae Colosi, 1920 to the rank of a full family, the Platythelphusidae, and assigned all six species of Platythelphusa to this family. Capart (1952), Bott (1955) and Coulter (1991), Colosi (1920) and Cumberlidge (1999) therefore proposed radically different versions of the higher taxonomy of the platythelphusids, each of which implies a different hypothesis for the phylogenetic origin of the group.

Preliminary cladistic studies (Sternberg and Cumberlidge, 1998; Cumberlidge, 1999 ) indicate that the six species of Platythelphusa form a closely related monophyletic group which has a distinctly separate ancestry from members of the genus Potamonautes (Potamonautidae), including the three species reported to be associated with Lake Tanganyika (Potamonautes lirrangensis, $P$. platynotus and $P$. loveridgei). This latter finding is in conflict with the published accounts of the group (Bott, 1955; Coulter, 1991) which place Platythelphusa as a subgenus within Potamonautes (Potamonautidae). To avoid confusion, the synonyms, family, genus, subgenus and subspecies categories used by Bott (1955) have not been recognized here.

Distribution. Known only from Lake Tanganyika, East Africa.

Ecology. Most of the fish and invertebrates found in Lake Tanganyika live in the oxygen-rich well-lit shallow waters close to the shores and little is known of the lifeforms that inhabit the deeper waters. The freshwater crabs of the genus Platythelphusa are all fully aquatic in habit and none have adopted the amphibious lifestyles characteristic of many of their relatives in the Potamonautidae that are 
found in the inland waters elsewhere in Africa (Cumberlidge, 1986, 1991, 1995, 1999; Cumberlidge and Sachs, 1991). Species of Platythelphusa are found from the shoreline down to $180 \mathrm{~m}$, and have become adapted to the different types of lake bed, which varies from rocks, sand, gravel and shell debris to soft mud (Capart, 1952; Coulter, 1991). Platythelphusa tuberculata is found only in the northern part of the lake in Burundi and Zaire, particularly where the lake bed is muddy, while P. echinata and $P$. conculata are typically found in the parts of the lake where the substratum is rocky. The large populations of aquatic snails found in the lake either serve as a source of food for some species of Platythelphusa (West et al., 1991; West and Cohen, 1994; Coulter, 1991), or their empty shells serve as a source of shelter for the juveniles of $P$. armata and the adults of smaller species such as $P$. maculata and P. polita (Coulter, 1991; Bills, 1996; present study).

Platythelphusa armata A. Milne-Edwards, 1887

(figures 1, 7a-b, 8a, g-h, 9a and 10a-d)

Platythelphusa armata A. Milne-Edwards, 1887: 147, pl. 2; Hilgendorf, 1898: 22, figure 1; Moore, 1903: 279; Rathbun, 1905: 269, pl. 21, figure 4; Cunnington, 1907: 268, figure 84; Balss, 1929: 352, 1936: 196; Chace, 1942: 224; Capart, 1952: 44-48, figure 1, 7a, 10; Cumberlidge, 1999.

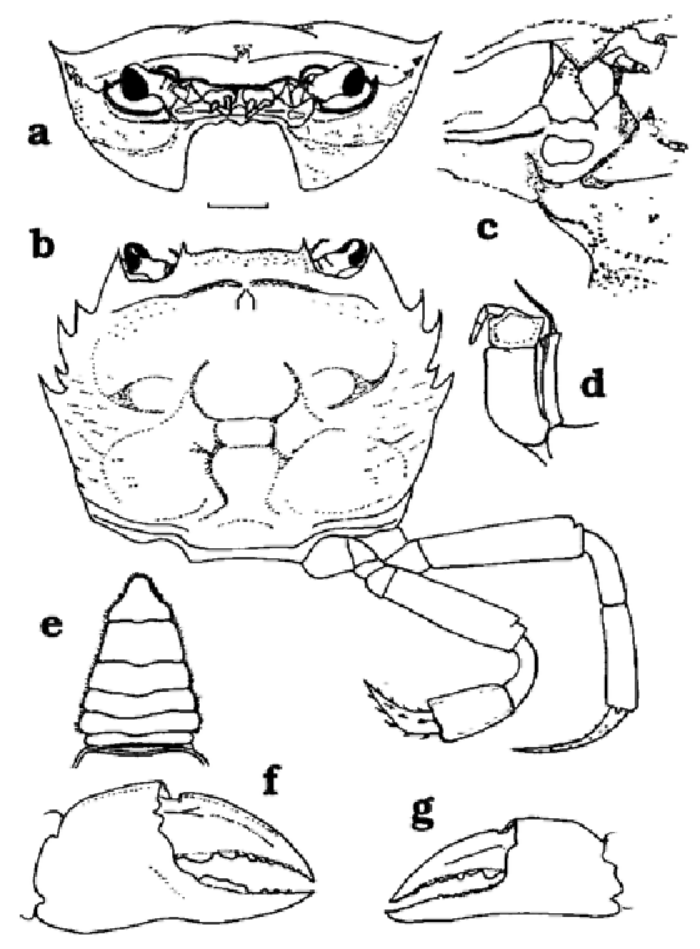

Fig. 1. Platythelphusa armata A. Milne-Edwards, 1887, adult male (cw $47 \mathrm{~mm}$ ) from Kalémié (Albertville), Lake Tanganyika, NHML 1952.10.23.1-10 (part). a, carapace, frontal aspect; b, carapace and right pereiopods P4 and P5, dorsal aspect; c, inferior view showing details of the left orbital region; $d$, left third maxilliped; e, abdomen; $f$, right cheliped, frontal view; $\mathrm{g}$, left cheliped, frontal view. Scale bar equals $8 \mathrm{~mm}(\mathrm{a}, \mathrm{b}, \mathrm{d}-\mathrm{g})$ and $3 \mathrm{~mm}$ (c). 


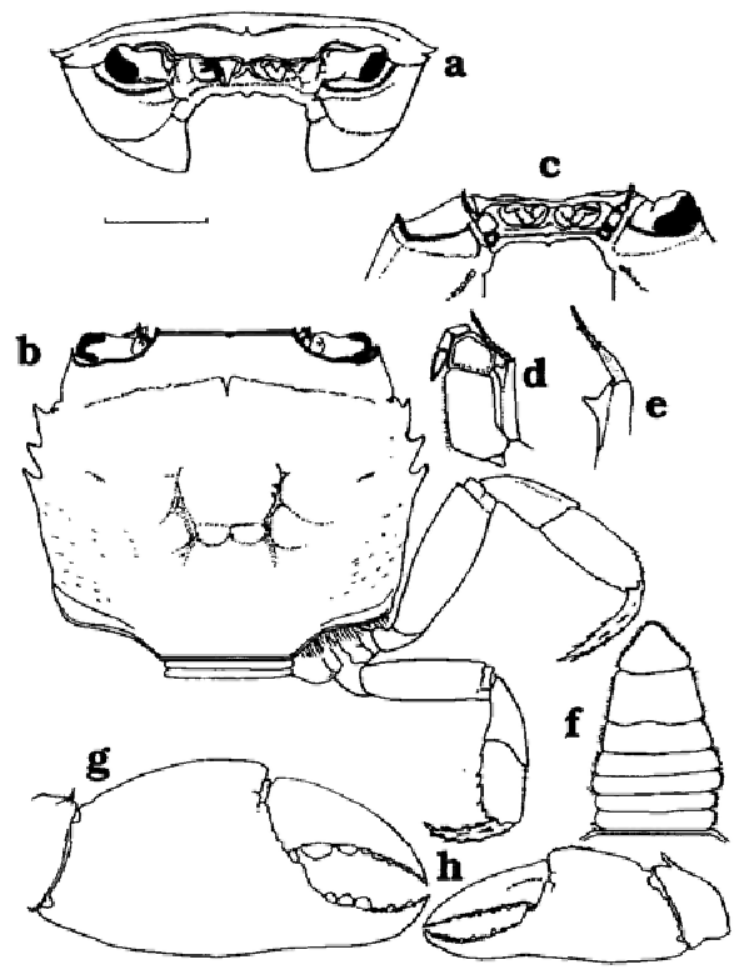

FIG. 2. Platythelphusa maculata (Cunnington, 1899), adult male syntype (cw $14 \mathrm{~mm}$ ) from Lake Tanganyika, Chituta Bay, Zambia, NHML 1899.6.14.1-2. a, carapace, frontal aspect; b, carapace and right pereiopods P4 and P5, dorsal aspect; c, inferior view of the frontal region; $d$, left third maxilliped; e, detail of the exopod of the third maxilliped; f, abdomen; g, right cheliped, frontal view; h, left cheliped, frontal view. Scale bar equals $4 \mathrm{~mm}(\mathrm{a}-\mathrm{d}, \mathrm{f}-\mathrm{h})$ and $2 \mathrm{~mm}$ (e).

Potamonautes (Platythelphusa) armata armata: Bott, 1955: 226-227, pl. 2, figures 1a-d, 9a-b; Coulter, 1991: 253-255, tables 9.XX, 9.XXI, figures 2, 3.

Material examined. Lake Tanganyika, south end; coll. Christy, 12 November 1929, $1 \mathrm{~m}$ ad., cw $37.8 \mathrm{~mm}$ (NHML 1929.11.12.1-2). Congo (formerly Zaire); Lake Tanganyika; Kalémié (formerly Albertville); $1 \mathrm{~m}$ ad., cw $47.5 \mathrm{~mm}$ (NHML 1952.10.23.1-10). Uvira, coll. G. Marlier, 3 October 1949 (MRAC 38942). Uvira; coll. J. Bouillon, 1953 (MRAC 47344-47348). Lufiro river (affluent of the Lualaba river), Buganmuru; coll. G. Marlier, 17 August 1949 (MRAC 38942). Burundi; Lake Tanganyika; Rumonge, shell beds, $7 \mathrm{~m}$ deep, on sandy slope; coll. I. R. Bills, 27 May 1993, 3 juv., cws 5.7, 10.3, $16.2 \mathrm{~mm}$ (CAW 23A). Muguruka, 10-40 m deep; coll. I. R. Bills, 12 June 1993, $2 \mathrm{~m}$ juv., cws $6.2,10.2 \mathrm{~mm}$, crabs inside empty gastropod shells (Neothauma tanganyicense Smith, 1880) (CAW 90). Lake Tanganyika, Vua, Kasakalawe; coll. W. A. Cunnington, Third Lake Tanganyika Expedition, $1 \mathrm{~m}$ ad., cw $47.0 \mathrm{~mm}$ (NHML 1908.1.31.1-3). Bujumbura, 12 November 1929, 1 f (NHML 1929.11-12-3). Lake Tanganyika, Bujumbura, coll. T. van den Audenaerde, January 1989 (MRAC 56.796). Zambia; Lake Tanganyika, Kombe Point, $1 \mathrm{~m}$ deep, lake bed sandy; coll. I. R. Bills, 15 March 1993, $1 \mathrm{~m}$ subad., cw $25.3 \mathrm{~mm}$, crabs inside empty gastropod shells ( $N$. tanganyicense) (CAW 9A). Musende Rocks, Mpulungu, $18 \mathrm{~m}$ 


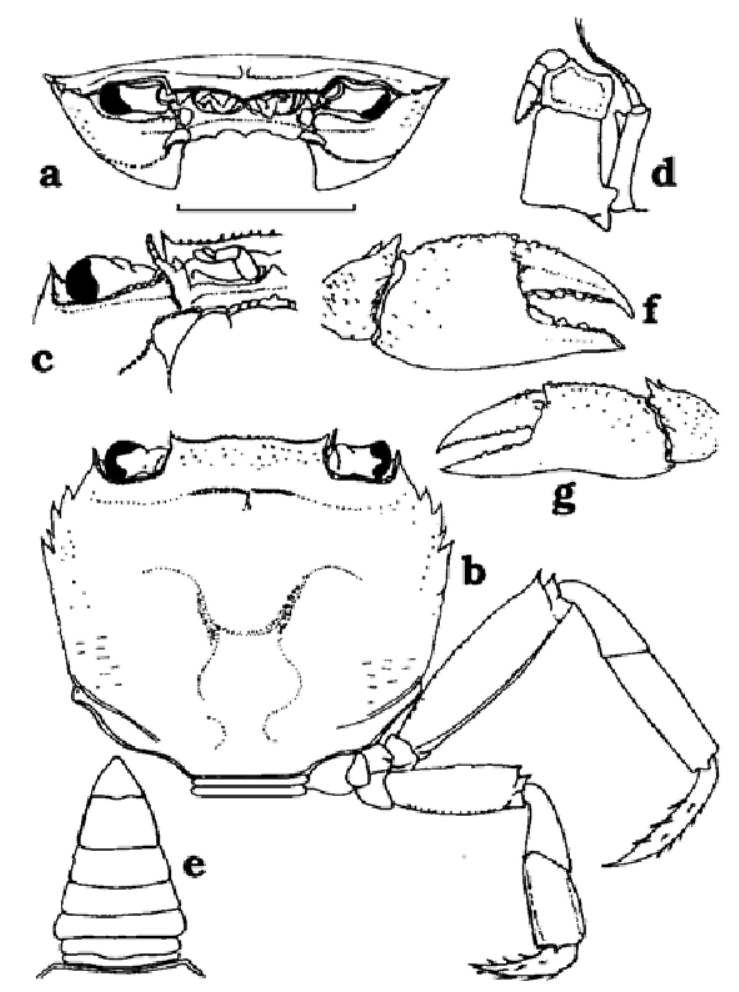

FIG. 3. Platythelphusa conculata Cunnington, 1907, adult male syntype (cw $10.8 \mathrm{~mm}$ ) from the south end of Lake Tanganyika. a, carapace, frontal aspect; $b$, carapace and right pereiopods P4 and P5, dorsal aspect; c, inferior view of the right orbital region; d, left third maxilliped; e, abdomen; f, right cheliped, frontal view; $g$, left cheliped, frontal view. Scale bar equals $5 \mathrm{~mm}(\mathrm{a}, \mathrm{b}, \mathrm{e}-\mathrm{g})$ and $3.5 \mathrm{~mm}(c, \mathrm{~d})$.

deep, lake bed muddy; coll. I. R. Bills, 7 January 1993, 2 m juv., cws 11.3, 14.3 mm; crabs inside empty gastropod shells ( $N$. tanganyicense) (CAW 17A). Mpulungu at Mbita Island, 20-25 m deep; coll. I. R. Bills, 17 October 1992, $1 \mathrm{f}$ subad., cw $15.6 \mathrm{~mm}$ (CAW 20A). Mwela; coll. I. R. Bills, 13 May 1992, $1 \mathrm{~m}$, subad., cw $25.4 \mathrm{~mm}$, collected together with $P$. conculata (CAW 60A). Musende Bay, near Sopelac Fishing Co., shell bed, on sandy/muddy lake bed; coll. I. R. Bills, 25 February 1992, 5 juv., cws $9.1,10.1,10.5,11.9,13.1 \mathrm{~mm}$, crabs inside empty gastropod shells ( $N$. tanganyicense), collected together with $P$. maculata (CAW 61A). Kombe Point; coll. I. R. Bills, 1 April 1992, 1 f subad., cw $21.9 \mathrm{~mm}$, collected together with $P$. conculata and juv. Potamonautes platynotus (CAW 62A). Mpulungu, Musende Bay (east), transect 3-2; coll. I. R. Bills, 1 March 1993, 17 juv., cws 8.7, 8.8, 9.5, 10.0, 10.2, $10.2,10.8,11.2,11.3,11.4,11.5,13.2,13.3,14.7,14.7,15.0,16.2 \mathrm{~mm}$, collected together with $P$. maculata (CAW 81A). Mpulungu, Musende Bay (east), transect A-1, 20 m deep, muddy lake bed; coll. I. R. Bills, 1 March 1993, 32 juv., cws 9.1, $9.5,9.8,9.3,9.9,10.4,10.7,10.8,10.9,10.1,10.8,10.8,10.3,10.9,12.8,12.0,12.3$, 13.0, 13.6, 13.6, 13.7, 14.7, 14.9 mm (CAW 82). Musende Bay, transect 3-3, 30A; coll. I. R. Bills, 1 March 1993, 13 juv., cws 9.5, 9.4, 9.8, 9.8. 9.9, 10.1, 10.6, 10.6, 10.8, 11.3, 11.4, 11.6, 15.6 mm (CAW 83). Mpulungu, Musende Bay, coast transect 4-4; coll. I. R. Bills, 1 March 1993, 21 juv., cws 9.0, 9.5, 9.7, 10.3, 10.6, 10.9, 10.9, 

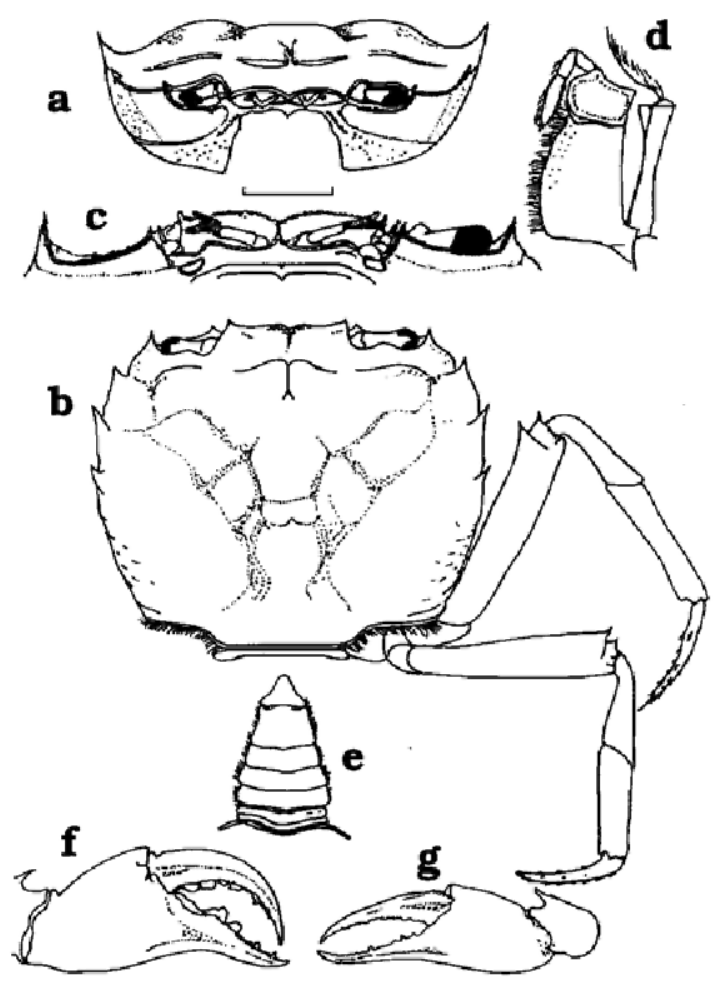

FIG. 4. Platythelphusa tuberculata Capart, 1952, adult male (cw $37.3 \mathrm{~mm}$ ) from Lake Tanganyika at the mouth of the Ruzizi river, in Burundi. a, carapace, frontal aspect; b, carapace and right pereiopods P4 and P5, dorsal aspect; c, inferior view of the frontal region; $\mathrm{d}$, left third maxilliped; e, abdomen; $\mathrm{f}$, right cheliped, frontal view; $\mathrm{g}$, left cheliped, frontal view. Scale bar equals $9 \mathrm{~mm}(\mathrm{a}, \mathrm{b}), 6 \mathrm{~mm}(\mathrm{c}, \mathrm{d}), 12 \mathrm{~mm}$ (e) and $18 \mathrm{~mm}$ (f, g).

$11.0,11.4,11.5,11.8,11.9,12.3,12.3,12.6,13.0,13.4,13.5,14.1,15.5,16.7 \mathrm{~mm}$ (CAW 84). Mpulungu, Musende Bay; coll. I. R. Bills, 21 February 1993, $8 \mathrm{~m}$ ad., cws $12.4,12.5,13.1,13.3,13.5,13.5,13.8,14.5 \mathrm{~mm}, 5 \mathrm{~m}$ subad., cws $9.6,9.7,10.4$, $10.8,11.0 \mathrm{~mm}, 1 \mathrm{f}$ ad., cw $13.8 \mathrm{~mm}$ (CAW 85A). Musende rocks, transect 3-3, 30C, $4 \mathrm{~m}$ deep; coll. I. R. Bills, 1 March 1993, 4 juv., cws 11.5, 11.8, 11.9, $13.2 \mathrm{~mm}$, crabs inside empty gastropod shells ( $N$. tanganyicense) (CAW 86). Kasakalawe, coll. H. Mathes, 4 January 1967 (MRAC 52.974). Johnson's Jetty, coll. H. Mathes, 21 July 1967, $1 \mathrm{f}$ ad., cw $44.9 \mathrm{~mm}$, hatchlings, cws $3.7 \mathrm{~mm}$ (MRAC 52.976). Tanzania; Gombe National Park, coll. R. Wrangham, 1 January 1973 (SMF).

Diagnosis. Carapace subhexagonal, rounded, not wide ( $\mathrm{cw} / \mathrm{fw} 2.58$ ), only a little wider than long (cl/fw 2.22), moderately high (ch/fw 0.98 ). Front indented slightly in middle, with a large forward pointing tooth at each external corner, and row of small granules along its edge. Epibranchial tooth large, pointed. Four teeth on anterolateral margin behind exorbital angle tooth (anteriormost is large epibranchial tooth, other three consisting of two large, subequal teeth and a smaller tooth). Suborbital margin lined by small pointed teeth, distinct spine at medial end. Margins of inferior surface of merus of cheliped both smooth or only faintly granulated, single large pointed distal tooth at distal end of medial inferior margin; 


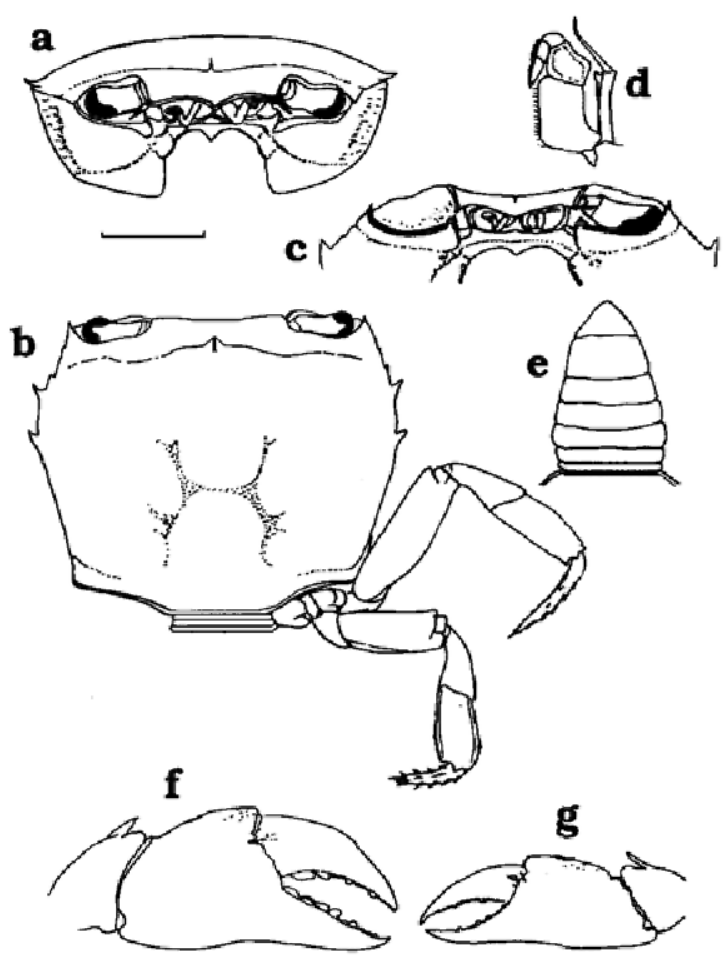

FIG. 5. Platythelphusa polita Capart, 1952, adult male syntype (cw $14 \mathrm{~mm}$ ) from Lake Tanganyika. a, carapace, frontal aspect; b, carapace and right pereiopods P4 and P5, dorsal aspect; $\mathrm{c}$, inferior view of the frontal region; $\mathrm{d}$, left third maxilliped; $\mathrm{e}$, abdomen; $\mathrm{f}$, right cheliped, frontal view; $\mathrm{g}$, left cheliped, frontal view. Scale bar equals $4 \mathrm{~mm}$ (a-e) and $5 \mathrm{~mm}$ (f, g).

superior margin of merus of $\mathrm{P} 1$ with rows of prominent, rough grains and short carinae. Inner margin of carpus of cheliped with two long slender pointed teeth (second as long as first); articular tooth between carpus and propodus of P1 long, pointed; outer margin of carpus with small granules. Merus of P5 a little longer than $\mathrm{fw}$, distal tooth of superior margin low, blunt. Propodus of P4 long, thin; propodus of P5 short, broad; margins of propodi of P5 widened, smooth. Terminal article of gonopod 1 directed sharply outward at a $90^{\circ}$ angle to the vertical; coneshaped, tapering to a pointed upward-directed tip.

Description. See A. Milne-Edwards (1887), Cunnington (1899, 1907, 1920), Capart (1952), Bott (1955) and Cumberlidge (1999).

Size. The adult size range is from $\mathrm{cw} 35.0$ to $47.5 \mathrm{~mm}$ (table 2). The carapace dimensions are given in figure 1; the carapace proportions are given in table 1.

Distribution. Lake Tanganyika: Burundi, Tanzania, Zambia and Zaire (table 3). For more localities see Capart (1952). Platythelphusa armata is the largest species in the genus and is probably the most common. The juveniles are found in the sublittoral shell zone from 1 to $60 \mathrm{~m}$ deep, in places where the lake bed is sandy or rocky, and they occur together with the adults of small species such as $P$. maculata, $P$. echinata and $P$. polita (Coulter, 1991; Bills, 1996; present study). The juveniles of $P$. armata are often found inside the empty shells of the gastropod Neothauma tanganyicense. 


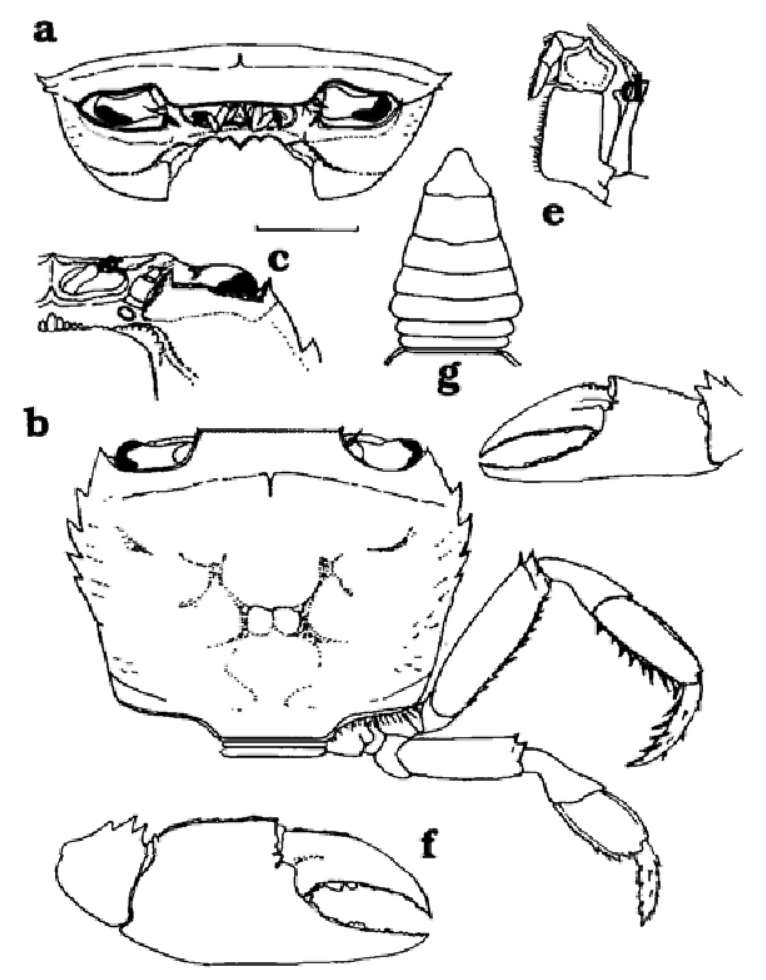

FIG. 6. Platythelphusa echinata Capart, 1952, adult male syntype (cw $15 \mathrm{~mm}$ ) from Lake Tanganyika, station 88 (near Malagarazi river), Tanzania, NHML 1952.10.23.23-27. a, carapace, frontal aspect; b, carapace and right pereiopods P4 and P5, dorsal aspect; $\mathrm{c}$, inferior view showing details of the left orbital region; $d$, left third maxilliped; e, abdomen; f, right cheliped, frontal view; g, left cheliped, frontal view. Scale bar equals $4 \mathrm{~mm}$ (a, b, d, e), $5 \mathrm{~mm}(\mathrm{f}, \mathrm{g})$ and $2.9 \mathrm{~mm}$ (c).

Remarks. Platythelphusa armata is characterized by large body size and heavy chelipeds, and by sharp pointed spines on the anterolateral margins of the carapace, frontal margin, suborbital margin and on the carpus of each cheliped. The distal tooth on the superior margin of the merus of pereiopods P2-P5 is low and blunt. Bott (1955) synonymized $P$. armata with Limnothelphusa maculata Cunnington, 1899. However, comparison of the type of $P$. armata (also see figures $1,8 \mathrm{a}, \mathrm{g}, \mathrm{h}$, $9 \mathrm{a}, 10 \mathrm{a}-\mathrm{d}$ and $11 \mathrm{a}$ ) with Cunnington's type of $L$. maculata (figures $2,8 \mathrm{~b}, \mathrm{k}, 1,9 \mathrm{~b}$, $10 \mathrm{e}-\mathrm{h}$ and $11 \mathrm{~b}$ ) indicates that these two taxa do not belong to the same species. It is more likely that each is a valid species (Capart, 1952; present study). Platythelphusa armata reach sexual maturity (where the abdomen is wide enough to reach the coxae of the chelipeds and where the entire abdomen completely covers the sternum) at cw $35-37 \mathrm{~mm}$. This permits the separation of young females $P$. armata from the adult females of other species which may already be mature at body sizes less than cw $35-37 \mathrm{~mm}$.

Platythelphusa maculata (Cunnington, 1899)

(figures $2,7 \mathrm{c}-\mathrm{d}, 8 \mathrm{~b}, \mathrm{i}-\mathrm{j}, 9 \mathrm{~b}$ and $10 \mathrm{e}-\mathrm{h}$ )

Limnothelphusa maculata Cunnington, 1899: 698, pl. 38; Moore, 1903: 280; Rathbun, 1905: 269. 


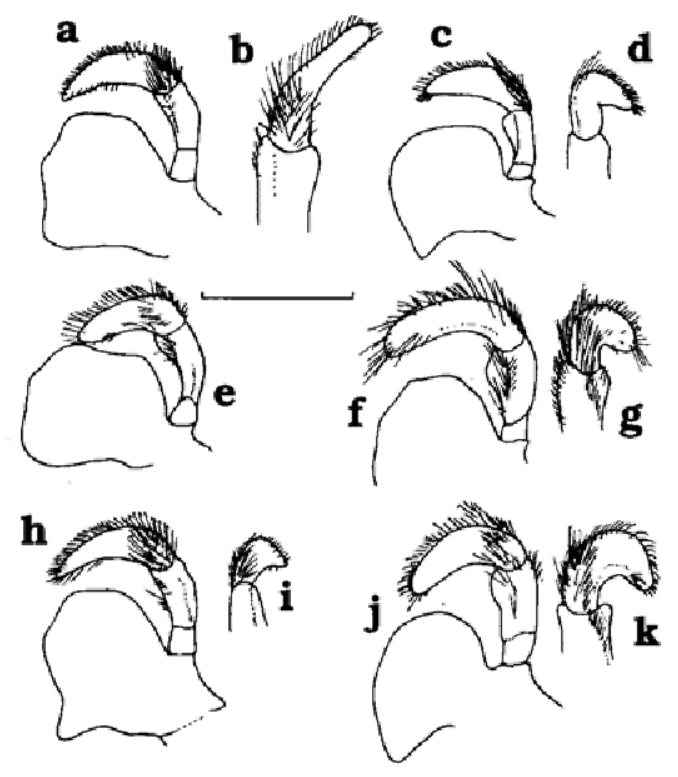

FIG. 7. Left mandible of Platythelphusa, frontal view and a superior view of the palp. a, b, $P$. armata, c, d, $P$. maculata; e, $P$. conculata; $f, g, P$. tuberculata; h, i, $P$. polita; , , k, $P$. echinata. Scale bar equals $3 \mathrm{~mm}$ (a, b, f-i), $1.5 \mathrm{~mm}(\mathrm{c}, \mathrm{d}, \mathrm{j}, \mathrm{k}$ ) and $1 \mathrm{~mm}$ (e).

Platythelphusa maculata Cunnington, 1907: 271, pl. 5-6; Cunnington, 1920: 557; Balss, 1936: 196; Chace, 1942: 225; Capart, 1952: 52-55, figures 5, 6, 7f, g.

Potamonautes (Platythelphusa) armata armata: Bott, 1955: 226-229, figure 9a-b, pl. 2, figure la-d.

Potamonautes (Platythelphusa) armata: Coulter, 1991: 253-255, tables 9.XX, 9.XXI.

Material examined. Lake Tanganyika, from deep water (between 20 and $160 \mathrm{~m}$ ); coll. J. E. S. Moore, 1896, $1 \mathrm{~m}$ ad., cw $14.5 \mathrm{~mm}, 1 \mathrm{f}$ ad., cw $12.8 \mathrm{~mm}$, syntypes (NHML 1899.6.14.1-2). Lake Tanganyika, from deep water (between 20 and $160 \mathrm{~m}$ ); coll. J. E. S. Moore, 1896, $1 \mathrm{~m}$ ad., cw $15.7 \mathrm{~mm}, 4 \mathrm{f}$ ad., cws 11.9, 11.9, 12.8, 14.6 mm, $2 \mathrm{~m}$ subad., cws $10.7,11.3 \mathrm{~mm}, 1 \mathrm{~m}$ juv., cw $8.7 \mathrm{~mm}$, syntypes (NHML 1899.6.14.3-5). Lake Tanganyika; coll. L. Stappers, 1 f ad., cw 15 mm (ZSM 1530/1 ex 1177/1). Zambia; Lake Tanganyika at Musende Bay, near Sopelac Fishing Co., shell bed, on sandy/muddy bottom; coll. I. R. Bills, 25 February 1992, $1 \mathrm{f}$ ad., cw $13.4 \mathrm{~mm}$, crabs inside empty gastropod shells ( $N$. tanganyicense), collected together with juv. P. armata (CAW 61A). Mpulungu, Musende Bay (east), transect 3-2; coll. I. R. Bills, 1 March 1993, 1 f ad., cw $15.5 \mathrm{~mm}$, collected together with juv. P. armata (CAW 81A).

Diagnosis. Carapace subhexagonal, rounded, not wide (cw/fw 2.44), only a little wider than long (cl/fw 2.07), very flat (ch/fw 0.86). Front indented slightly in middle, with row of small granules along its edge, small low tooth at each external corner. Exorbital angle produced into sharp forward-directed pointed tooth, epibranchial tooth large, pointed. Three teeth on anterolateral margin behind exorbital angle tooth (anteriormost the large epibranchial tooth, the other two are large, subequal, teeth). Suborbital margin lined by granules, broad low tooth at medial end. Margins of inferior surface of merus of cheliped lined by small granules, single 

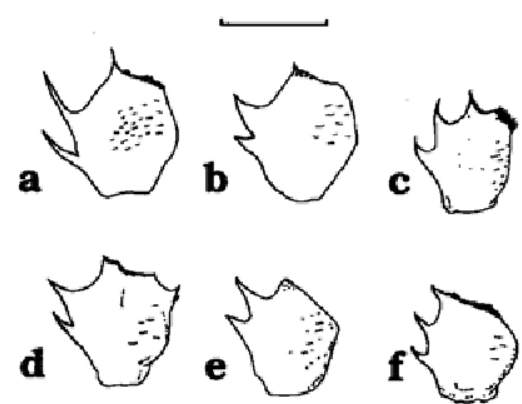<smiles>[Y]1[C][C][C]CC1</smiles>
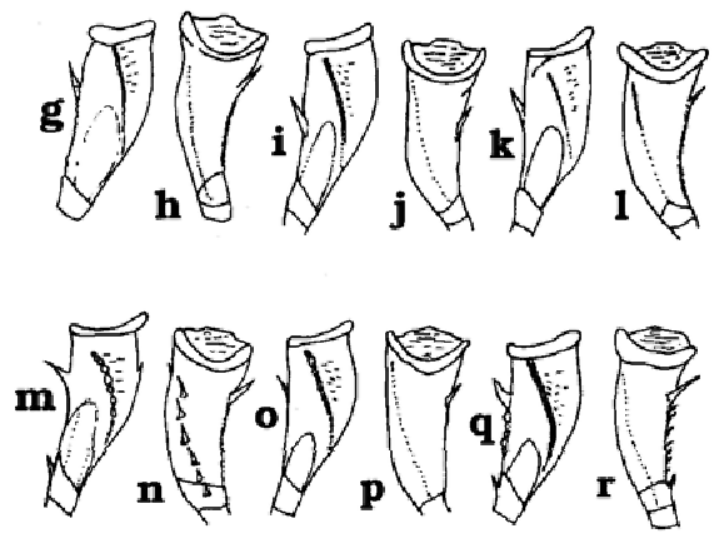

FIG. 8. Superior view of the carpus of the cheliped (pereiopod 1) of adult males of Platythelphusa. a, P. armata, b, P. maculata; c, P. conculata; d, P. tuberculata; e, $P$. polita; $\mathrm{f}, P$. echinata. Superior and inferior views of the merus of the cheliped (pereiopod 1) of adult males of Platythelphusa. g, h, P. armata; i, j, P. maculata; $\mathrm{k}, \mathrm{l}$, $P$. conculata $; \mathrm{m}, \mathrm{n}, P$. tuberculata; $\mathrm{o}, \mathrm{p}, P$. polita; $\mathrm{q}, \mathrm{r}, P$. echinata. Scale bar equals $14 \mathrm{~mm}$ (a, d, g, h, m, n), $5.3 \mathrm{~mm}(\mathrm{~b}, \mathrm{e}, \mathrm{f}, \mathrm{i}, \mathrm{j}, \mathrm{o}-\mathrm{r})$ and $3 \mathrm{~mm} \mathrm{(c,} \mathrm{k,} \mathrm{l).}$

large pointed distal tooth on medial inferior margin; superior margin of merus of P1 with rows of short carinae. Inner margin of carpus of cheliped with two large teeth, second smaller than first, articular tooth (at point of articulation with propodus) small, pointed; outer margin of carpus smooth. Merus of P5 about as long as fw, distal tooth on superior margin low, round. Propodus of P4 long, broad; propodus of P5 short, broad; inferior margin of propodus of P5 widened, toothed. Terminal article of gonopod 1 directed outward at a $45^{\circ}$ angle to the vertical, stout, straight, cone-like, tapering to pointed tip.

Description. See Cunnington (1907) and Capart (1952).

Size. The adult size range is from $\mathrm{cw} 12.5$ to $15.7 \mathrm{~mm}$ (table 2). The carapace dimensions are given in figure 11; the carapace proportions are given in table 1 .

Distribution. Lake Tanganyika: Zambia (table 3). For more localities see Capart (1952). This species occurs in waters from 1 to $60 \mathrm{~m}$ deep, on sand or rocks, sometimes inside empty Neothauma shells.

Remarks. Bott (1955) treated P. maculata as a synonym of $P$. armata. This follows the opinion of Balss (1936) that the specimens described by Cunnington (1899) as Limnothelphusa maculata were, in fact, juvenile forms of $P$. armata. These same specimens of $P$. maculata were examined in the present study. Platythelphusa 


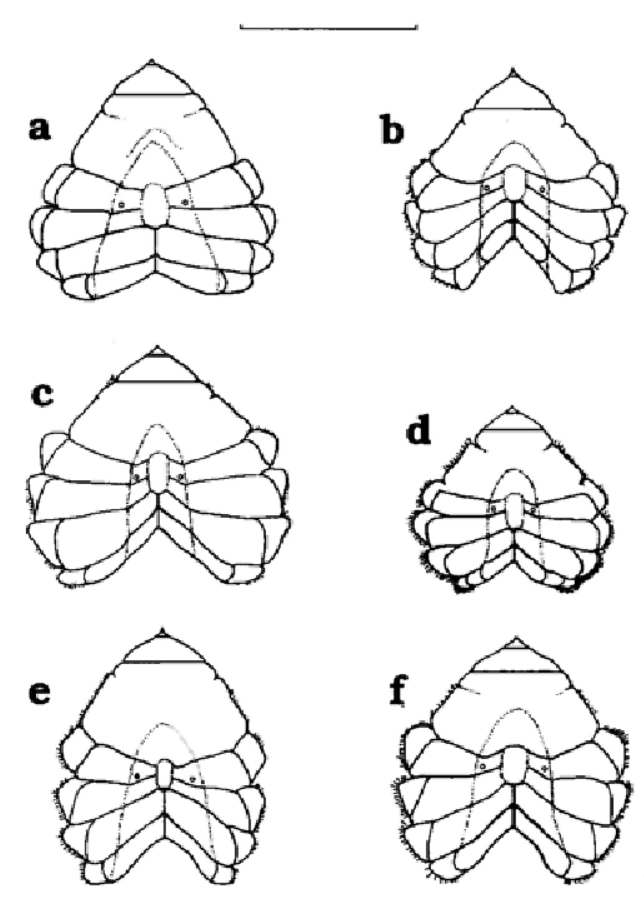

FIG. 9. Inferior view of the sternum of adult males of Platythelphusa. a, P. armata, b, $P$. maculata; c, P. conculata; d, P. tuberculata; e, P. polita; $\mathrm{f}, P$. echinata. Scale bar equals $5 \mathrm{~mm}(\mathrm{c}), 7 \mathrm{~mm}(\mathrm{~b}, \mathrm{e}, \mathrm{f})$ and $23 \mathrm{~mm}(\mathrm{a}, \mathrm{d})$.

maculata reach maturity at an extremely small size: adult females with a cw of only $12.4 \mathrm{~mm}$ are ovigerous, while female $P$. armata measuring $\mathrm{cw} 12-15 \mathrm{~mm}$ would be juveniles 'and would not mature until they reach $\mathrm{cw} 35 \mathrm{~mm}$. This argues against the synonymy of $P$. maculata with $P$. armata.

Platythelphusa maculata was recognized by Capart (1952), and is recognized here, as a valid species following comparison of the type material of $P$. armata and $P$. maculata. Adult $P$. maculata do indeed superficially resemble juvenile forms of $P$. armata. Platythelphusa maculata can therefore be distinguished from both $P$. armata and $P$. tuberculata by its smaller body size at maturity. In addition, $P$. maculata can be distinguished from both $P$. armata and $P$. tuberculata by its smoother, less sculptured, and flatter carapace (ch/fw 0.86 for the former, 1.00 and 1.14 for the latter two taxa).

Platythelphusa maculata can be distinguished from $P$. polita by its flatter carapace (ch/fw 0.86 for the former, 1.06 for the latter) and by the number of spines on the anterolateral carapace (three in $P$. maculata, two in $P$. polita). Platythelphusa maculata can be distinguished from the two other species of small crabs with a flat carapace ( $P$. conculata and $P$. echinata) as follows. Gonopod 1 of $P$. maculata is angled at $90^{\circ}$ to the vertical, while in both $P$. conculata and $P$. echinata it is angled at $45^{\circ}$ to the vertical; the inferior margin of the propodus of $\mathrm{P} 5$ is spiny in $P$. maculata and smooth in $P$. conculata; and the tooth on the superior margin of the merus of P2-P5 is distinct and pointed in P. echinata and low or absent in P. maculata. 


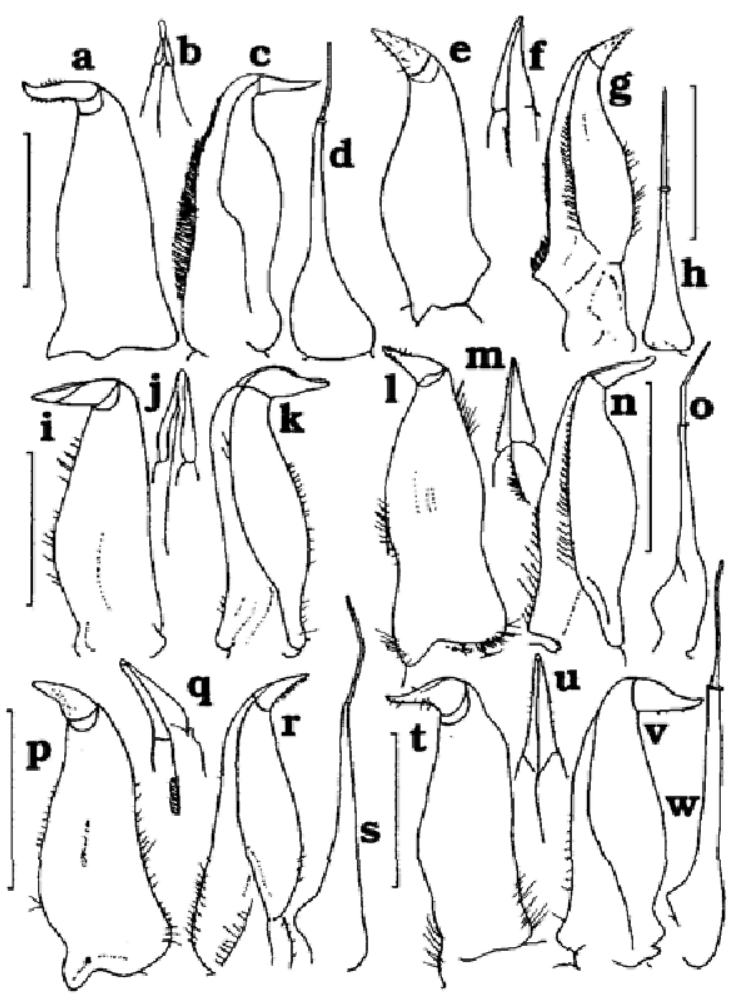

FIG. 10. Right first gonopod (dorsal view; superior view; ventral view) of adult males of Platythelphusa. a-c, $P$. armata; $\mathrm{e}-\mathrm{g}, P$. maculata; $\mathrm{i}-\mathrm{k}, P$. conculata; $1-\mathrm{n}, P$. tuberculata; $\mathrm{p}-\mathrm{r}, P$. polita; $\mathrm{t}-\mathrm{v}$, P. echinata. Right second gonopod (dorsal view) of adult males of Platythelphusa. d, P. armata; h, P. maculata; $;$, P. tuberculata; $\mathrm{s}, P$. echinata $; \mathrm{w}, P$. polita. Scale bars equal $5 \mathrm{~mm}$ (a-d), $1.5 \mathrm{~mm}(\mathrm{e}-\mathrm{g}, \mathrm{t}, \mathrm{v}, \mathrm{w}), 1 \mathrm{~mm}(\mathrm{i}-\mathrm{k}), 0.25 \mathrm{~mm}$ (h) and $0.12 \mathrm{~mm}$ (u). Scale bars equal $3 \mathrm{~mm}(1, \mathrm{~m})$ and $3.7 \mathrm{~mm}(\mathrm{o})$; scale bars equal $2 \mathrm{~mm}(\mathrm{p}-\mathrm{s})$.

FIG. 11. Comparisons of the dimensions of the carapace ( $\mathrm{cw}=\mathrm{square}, \mathrm{ch}=$ triangle, $\mathrm{cl}=$ circle) compared to front width ( $\mathrm{fw}$ ) of Platythelphusa. Relationships for each species are described by the regression equations. A, 131 specimens of $P$. armata ranging in size from $\mathrm{cw} 6.2$ to $47.5 \mathrm{~mm}$. $\mathrm{cw}=3.01 \mathrm{fw}-2.85, r=0.99 ; \mathrm{cl}=2.55 \mathrm{fw}-2.21, r=0.99$; $\mathrm{ch}=0.98 \mathrm{fw}+0.14, r=0.99$. All $r$ values indicate a highly significant correlation $(P<0.001)$ at 130 degrees of freedom. B, 12 specimens of $P$. maculata ranging in size from $\mathrm{cw} 8.7$ to $15.7 \mathrm{~mm}$. $\mathrm{cw}=2.23 \mathrm{fw}+0.94, r=0.93 ; \mathrm{cl}=1.92 \mathrm{fw}+0.75, r=0.93 ; \mathrm{ch}=$ $0.85 \mathrm{fw}+0.05, r=0.82$. All $r$ values indicate a highly significant correlation $(P<0.001)$ at 11 degrees of freedom. $C, 22$ specimens of $P$. conculata ranging in size from cw 7.5 to $17.7 \mathrm{~mm}$. $\mathrm{cw}=2.54 \mathrm{fw}-0.76, r=0.98 ; \mathrm{cl}=2.18 \mathrm{fw}-0.38, r=0.98 ; \mathrm{ch}=1.05 \mathrm{fw}-1.49$, $r=0.95$. All $r$ values indicate a highly significant correlation $(P<0.001)$ at 21 degrees of freedom. D, 4 specimens of $P$. tuberculata ranging in size from $\mathrm{cw} 16.4$ to $37.3 \mathrm{~mm}$. $\mathrm{cw}=3.04 \mathrm{fw}-0.50, r=0.99 ; \mathrm{cl}=2.54 \mathrm{fw}-0.27, r=0.99 ; \mathrm{ch}=1.28 \mathrm{fw}-1.04 r=0.97$. All $r$ values indicate a highly significant correlation $(P<0.001)$ at 3 degrees of freedom. $\mathbf{E}$, 61 specimens of $P$. polita ranging in size from $\mathrm{cw} 2.7$ to $18.0 \mathrm{~mm}$. $\mathrm{cw}=2.40 \mathrm{fw}+0.09$, $r=0.97 ; \mathrm{cl}=0.74+1.89 \mathrm{fw}, r=0.97 ; \mathrm{ch}=1.26 \mathrm{fw}-1.00, r=0.90$. All $r$ values indicate a highly significant correlation $(P<0.001)$ at 60 degrees of freedom. F, 23 specimens of $P$. echinata ranging in size from $\mathrm{cw} 7.45$ to $20.9 \mathrm{~mm}$. $\mathrm{cw}=2.64 \mathrm{fw}-1.22, r=0.98$; $\mathrm{cl}=1.99 \mathrm{fw}+0.17, r=0.97 ; \mathrm{ch}=1.02 \mathrm{fw}-1.46, r=0.94$. All $r$ values indicate a highly significant correlation $(P<0.001)$ at 22 degrees of freedom. 

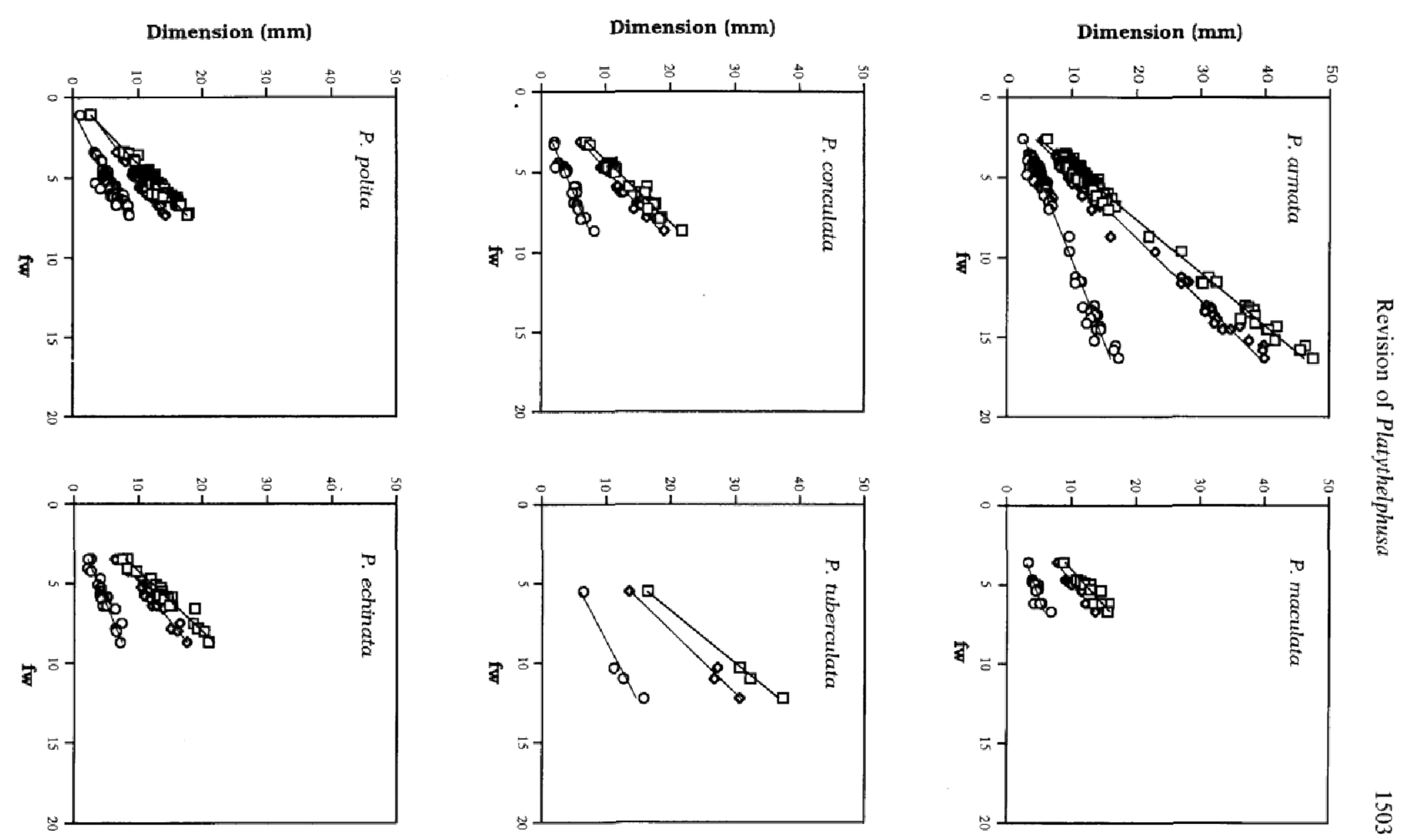
Table 1. Platythelphusa: carapace proportions.

\begin{tabular}{lcccccr}
\hline Species & \multicolumn{2}{c}{$\mathrm{cw} / \mathrm{fw} \pm \mathrm{SD}$} & \multicolumn{2}{c}{$\mathrm{cl} / \mathrm{fw} \pm \mathrm{SD}$} & \multicolumn{2}{c}{$\mathrm{ch} / \mathrm{fw} \pm \mathrm{SD}$} \\
\hline P. tuberculata $(n=4)$ & 2.95 & 0.03 & 2.49 & 0.10 & 1.14 & 0.04 \\
$P$. armata $(n=131)$ & 2.47 & 0.18 & 2.13 & 0.15 & 1.00 & 0.08 \\
$P$. conculata $(n=22)$ & 2.40 & 0.13 & 2.11 & 0.10 & 0.77 & 0.12 \\
P. maculata $(n=12)$ & 2.41 & 0.14 & 2.06 & 0.12 & 0.86 & 0.08 \\
P. echinata $(n=23)$ & 2.42 & 0.16 & 2.03 & 0.13 & 0.76 & 0.11 \\
$P$. polita $(n=61)$ & 2.42 & 0.12 & 2.04 & 0.10 & 1.06 & 0.11 \\
\hline
\end{tabular}

Table 2. Size range of the species of Platythelphusa. The range of the moult of puberty was estimated as the carapace width of the largest subadult female to the carapace width of the smallest adult female.

\begin{tabular}{lcc}
\hline & $\begin{array}{c}\text { Moult of puberty } \\
\text { (cw mm) }\end{array}$ & $\begin{array}{c}\text { Largest known specimen } \\
\text { (cw mm) }\end{array}$ \\
\hline Platythelphusa armata & $35-37$ & 47.5 \\
Platythelphusa tuberculata & $?$ & 37.3 \\
Platythelphusa echinata & 16.0 & 20.9 \\
Platythelphusa polita & $12-13$ & 18.0 \\
Platythelphusa maculata & 12.5 & 15.7 \\
Platythelphusa conculata & 15.0 & 21.8 \\
\hline
\end{tabular}

Platythelphusa conculata Cunnington, 1907

(figures $3,7 \mathrm{e}, 8 \mathrm{c}, \mathrm{k}-1,9 \mathrm{c}$ and $10 \mathrm{i}-\mathrm{k}$ )

Platythelphusa conculata Cunnington, 1907: 273, pl. 13, figure 2, 4; Chace, 1942: 225; Capart, 1952: 60 .

Platythelphusa denticulata Capart, 1952: 48-50, figures 2, 7b.

Potamonatutes (Platythelphusa) armata conculata: Bott, 1955: 228-229, figures 10a, b, pl. $2,2 \mathrm{a}-\mathrm{d}$

Potamonautes (Platythelphusa) conculata: Coulter, 1991: 253-255, tables 9.XX, 9.XXI.

Material examined. Lake Tanganyika, south end; $1 \mathrm{~m}$ juv., $\mathrm{cw} 10.8 \mathrm{~mm}$, holotype (NHML 1908.1.31.15). Congo (formerly Zaire); Lake Tanganyika, northwest shore; coll. Grauer, February 1910, 1 f ad., cw $20 \mathrm{~mm}$ (NHMW 13365). Burundi; Lake Tanganyika, Kigoma Bay, at Luansa Point, 2-5m deep; coll. I. R. Bills, 22 May 1993, 1 f ad., cw $18.4 \mathrm{~mm}$, rocky lake bed (CAW 19A). Zambia; Lake Tanganyika, Chituta Bay, 5m deep; coll. I. R. Bills, 9 March 1993, 3 juv., cws 10.2, $10.9,11.5 \mathrm{~mm}$, crabs under rocks (CAW 18A, B, C, D). Lake Tanganyika, Onzye Island rocks, east of Mpulungu; coll. I. R. Bills, 10 March, 1993, $1 \mathrm{f}$ subad., cw $16.5 \mathrm{~mm}, 2 \mathrm{~m}$ subad., cws 11.7, 16.1 mm (CAW 22A). Mwela, southwest shore; coll. I. R. Bills, 13 May 1992, 2 f ad., cws 18.7, $21.8 \mathrm{~mm}$; 3 f subad., cws 11.1, 11.3, $11.5 \mathrm{~mm}, 2 \mathrm{~m}$ subad., cws 13.7, $15.5 \mathrm{~mm}$ (CAW 60A). Kombe Point, west coast, $5 \mathrm{~m}$ deep; coll. I. R. Bills, 1 April 1992, 4 f ad., cw 15.6, 17.0, 17.0, $17.3 \mathrm{~mm}, 1 \mathrm{f}$ juv., cw $10.0 \mathrm{~mm}, 2 \mathrm{~m}$ juv., cws $6.9,9.2 \mathrm{~mm}$; collected together with juv. $P$. armata and juv. Potamonautes platynotus (CAW 62A).

Diagnosis. Carapace subhexagonal, rounded, not wide ( $\mathrm{cw} / \mathrm{fw} 2.44)$, only a little wider than long (cl/fw 2.11), very flat (ch/fw 0.75 ). Front indented slightly in middle, with row of small granules along its edge, with distinct forward pointing tooth at each external corner. Exorbital angle produced into forward-directed pointed tooth, epibranchial tooth large, pointed. Four large subequal forward pointing 
Table 3. Gazetteer of localities for Platythelphusa in Lake Tanganyika (present study).

\begin{tabular}{ll}
\hline Burundi (1, 3, 4, 5, 6) & \\
\hline Ruzizi river mouth (4) & $03^{\circ} 21^{\prime} 15^{\prime \prime} \mathrm{S}, 29^{\circ} 16^{\prime} 50^{\prime \prime} \mathrm{E}$ \\
Bujumbura & $03^{\circ} 23^{\prime} \mathrm{S}, 29^{\circ} 21^{\prime} \mathrm{E}$ \\
Magara (= Makara) (6) & $03^{\circ} 43^{\prime} 50^{\prime \prime} \mathrm{S}, 29^{\circ} 20^{\prime} 50^{\prime \prime} \mathrm{E}$ \\
Rumonge (1) & $03^{\circ} 45^{\prime} 20^{\prime \prime} \mathrm{S}, 29^{\circ} 25^{\prime} 35^{\prime \prime} \mathrm{E}$ \\
Near Gitaza, 25 km south of Bujumbura (5) & $03^{\circ} 46^{\prime} 50^{\prime \prime} \mathrm{S}, 29^{\circ} 20^{\prime} 35^{\prime \prime} \mathrm{E}$ \\
Kigoma Bay, at Luansa Point (3) & $04^{\circ} 51^{\prime} 15^{\prime \prime} \mathrm{S}, 29^{\circ} 37^{\prime} 25^{\prime \prime} \mathrm{E}$ \\
Democratic Republic of Congo (formerly Zaire) (1, 3, 4, 5) & \\
Northwest shore of Lake Tanganyika (3) & \\
Uvira (1) & $\mathrm{Exact} l l^{\circ} \mathrm{ocation}$ unknown \\
Kalémié (Albertville) (1) & $03^{\circ} 25^{\prime} \mathrm{S}, 29^{\circ} 08^{\prime} \mathrm{E}$ \\
Katibili Bay (5) & $05^{\circ} 55^{\prime} \mathrm{S}, 29^{\circ} 16^{\prime} \mathrm{E}$ \\
Tembwe Bay (5) & $06^{\circ} 05^{\prime} \mathrm{S}, 29^{\circ} 18^{\prime} \mathrm{E}$ \\
Moba (4) & $06^{\circ} 30^{\prime} \mathrm{S}, 29^{\circ} 28^{\prime} \mathrm{E}$ \\
Lufiro river (affluent of the Lualaba river), Buganmuru (1) & $07^{\circ} 02^{\prime} \mathrm{S}, 29^{\circ} 50^{\prime} \mathrm{E}$ \\
Tanzania (1, 5) & $10^{\circ} 10^{\prime} \mathrm{S}, 27^{\circ} 20^{\prime} \mathrm{E}$ \\
Malagarazi river (5) & \\
Gombe National Park (1) & \\
South of Kabwe, Utinta Bay (5) & $05^{\circ} 05^{\prime} \mathrm{S}, 29^{\circ} 50^{\prime} \mathrm{E}$ \\
Zambia (1, 2, 3) & $05^{\circ} 30^{\prime} \mathrm{S}, 29^{\circ} 40^{\prime} \mathrm{E}$ \\
Mwela, southwest shore (1, 3) & $07^{\circ} 00^{\prime} \mathrm{S}, 30^{\circ} 36^{\prime} \mathrm{E}$ \\
Chituta Bay (3) & \\
Onzye Island Rocks, east of Mpulungu, (3) & \\
Mpulungu at Mbita Island, northwest shore (1) & $08^{\circ} 43^{\prime} 30^{\prime \prime} \mathrm{S}, 30^{\circ} 57^{\prime} 00^{\prime \prime} \mathrm{E}$ \\
Mpulungu, Musende Rocks (1) & $08^{\circ} 43^{\prime} 55^{\prime \prime} \mathrm{S}, 31^{\circ} 09^{\prime} 40^{\prime \prime} \mathrm{E}$ \\
Mpulungu, Musende Bay (1, 2) & $08^{\circ} 44^{\prime} 00^{\prime \prime} \mathrm{S}, 31^{\circ} 07^{\prime} 55^{\prime \prime} \mathrm{E}$ \\
Kombe Point, west coast (1, 3) & $08^{\circ} 44^{\prime} 25^{\prime \prime} \mathrm{S}, 31^{\circ} 05^{\prime} 45^{\prime \prime} \mathrm{E}$ \\
\hline & $08^{\circ} 45^{\prime} 50^{\prime \prime} \mathrm{S}, 31^{\circ} 05^{\prime} 55^{\prime \prime} \mathrm{E}$ \\
\hline & $08^{\circ} 45^{\prime} 50^{\prime \prime} \mathrm{S}, 31^{\circ} 05^{\prime} 55^{\prime \prime} \mathrm{E}$ \\
$08^{\circ} 47^{\prime} 35^{\prime \prime} \mathrm{S}, 31^{\circ} 01^{\prime} 15^{\prime \prime} \mathrm{E}$ \\
\hline
\end{tabular}

$1=$ Platythelphusa armata, $2=P$. maculata, $3=P$. conculata, $4=P$. tuberculata, $5=P$. polita, $6=P$. echinata .

teeth on anterolateral margin (anteriormost being epibranchial tooth). Suborbital margin lined by small teeth, larger tooth at medial end. Margins of inferior surface of merus of cheliped lined by small granules, single large pointed tooth on medial inferior margin; superior margin of merus of P1 with rows of short carinae. Inner margin of carpus of cheliped with two large subequal carpal teeth, articular tooth (at point of articulation with propodus) sharp, pointed; outer margin of carpus lined by row of small thin sharp spines. Merus of P5 about as long as fw, distal tooth on superior margin of P2-P5 sharp, pointed. Propodus of P4 and P5 long, thin margins of propodus of $\mathrm{P} 5$ widened, smooth. Terminal article of gonopod 1 directed sharply outward at a $90^{\circ}$ angle to the vertical, slim, cone-shaped, tapering to pointed tip.

Description. See Cunnington (1907) and Capart (1952).

Size. The adult size range in our specimens is from $\mathrm{cw} 15$ to $21.8 \mathrm{~mm}$ (table 2). This species may reach larger sizes because the specimen of $P$. denticulata illustrated - by Capart (1952) is an adult female ( $\mathrm{cw} 46 \mathrm{~mm}$ ). The carapace dimensions are presented in figure 11; the carapace proportions are given in table 1.

Distribution. Lake Tanganyika: Burundi, Zambia and Zaire (table 3). For more localities see Capart (1952). Collected in the lake from depths between 20 and $60 \mathrm{~m}$.

Remarks. Capart (1952) did not recognize $P$. conculata as a valid species, because he thought that the type of $P$. conculata may be either $P$. maculata or a 
juvenile form of $P$. armata. Furthermore, Bott (1955) considered $P$. conculata to be a subspecies of $P$. armata. We have not examined the type of $P$. denticulata. However, the figure of $P$. denticulata provided by Capart (1952, figure 2) clearly shows the distinctive carpus of $\mathrm{P} 1$ that is characteristic of $P$. conculata: two large subequal carpal teeth, a sharp and pointed articular tooth and an outer margin that is lined by a row of long, thin distinct spines. In addition, the figure of $P$. denticulata provided by Capart (1952, figure 2) clearly shows the distinctive anterolateral margin tooth pattern that is characteristic of $P$. conculata: four subequal forward pointing teeth on the anterolateral margin. For these reasons, $P$. denticulata of Capart (1952) is considered here to be a synonym of $P$. conculata.

Platythelphusa conculata is recognized here as a valid species following comparison of the type material of $P$. armata and $P$. conculata. There are clear differences between $P$. conculata and $P$. armata. These include the body size at maturity (cw $15-21.8 \mathrm{~mm}$ in $P$. conculata and $\mathrm{cw} 35-37 \mathrm{~mm}$ in $P$. armata), the carapace height (very flat in $P$. conculata and medium high in $P$. armata), the distal tooth on the superior margin of P2-P5 (a sharp spine in P. conculata, low and blunt in P. armata), the outer margin of the carpus of pereiopod 1 (a row of thin sharp spines in $P$. conculata, and smooth or granular in $P$. armata), and the angle of the terminal article of gonopod 1 which is $45^{\circ}$ to the vertical in $P$. conculata and $90^{\circ}$ to the vertical in $P$. armata.

Platythelphusa conculata can be distinguished from other small species as follows. The terminal article of gonopod 1 of $P$. conculata is angled at $45^{\circ}$ to the vertical while that of $P$. maculata is angled at $90^{\circ}$ to the vertical. In addition, the distal tooth on the superior margin of P2-P5 of $P$. conculata is a sharp spine while that of $P$. maculata is low and blunt, and the inferior margin of the propodus of P5 of $P$. conculata is smooth, while that of $P$. maculata is spiny. Differences between $P$. conculata and $P$. echinata include the inferior margin of the propodus of P2-P5 (which is smooth in $P$. conculata and very spiny in $P$. echinata), and the margin of the merus of P1 (which is smooth in $P$. conculata and very spiny in $P$. echinata).

Platythelphusa tuberculata Capart, 1952

(figures $4,7 \mathrm{f}-\mathrm{g}, 8 \mathrm{~d}, \mathrm{~m}, \mathrm{n}, 9 \mathrm{~d}$ and $101-\mathrm{o}$ )

Platythelphusa tuberculata Capart, 1952: 50-52, figures 4, 7c.

Potamonautes (Platythelphusa) tuberculata Coulter, 1991: 253-255, tables 9.XX, 9.XXI.

Material examined. Congo (formerly Zaire); Lake Tanganyika, vicinity of Moba, $20 \mathrm{~m}$ deep (station 38); don. A. Capart, 23 October 1952, $1 \mathrm{~m}$ subad., cw $16.4 \mathrm{~mm}$, syntype (NHML 1952.10.23.28). Burundi; Ruzizi river mouth, $15-30 \mathrm{~m}$ deep; 1 June 1993, $2 \mathrm{~m}$ ad., cws $37.3,31.4 \mathrm{~mm}, 1 \mathrm{f}$ ad., cw $30.6 \mathrm{~mm}$, lake bed soft mud, caught in gill nets (CAW 12A).

Diagnosis. Carapace subhexagonal, rounded, wide (cw/fw 2.95), very long (cl/fw 2.49), very high (ch/fw 1.14). Front indented in middle, with row of small granules along its edge, with distinct forward-pointing tooth at each external corner. Exorbital angle produced into forward-directed pointed tooth, epibranchial tooth large, pointed. Three large, subequal, forward pointing teeth on anterolateral margin (the anteriormost is the epibranchial tooth). Suborbital margin lined by small granules, large pointed tooth at medial end. Epimeral sulcus on sidewalls of carapace, vertical sulcus between epimeral sulcus and base of epibranchial tooth. Lateral inferior margin of merus of cheliped lined by series of distinct pointed teeth, single 
large pointed tooth on medial inferior margin; superior margin with single spine or carinae. Inner margin of carpus of cheliped with two large subequal medial teeth, articular tooth (at point of articulation with propodus) broad, pointed, low; outer margin of carpus with row of small granules and posterior spine. Coxa of cheliped with sharp spine on inferior lateral margin. Merus of P5 much longer than fw, superior margin with sharp distal tooth. Propodi of P4, P5 extremely long, thin margins of propodi of P4, P5 smooth. Dactyli of P2-P5 very long, slim, curved, rows of spines very reduced. Terminal article of gonopod 1 directed outward at a $60^{\circ}$ angle to vertical, slim, cone-shaped, tapering to pointed tip.

Description. See Capart (1952).

Size. The adult size range is from $\mathrm{cw} 30.6$ to $37.3 \mathrm{~mm}$ (table 2). The carapace dimensions are presented in figure 11; the carapace proportions are given in table 1.

Distribution. Lake Tanganyika: Burundi, Zaire (table 3). Collected in waters $20-50 \mathrm{~m}$ deep where the lake bed is muddy. The type locality is at Moba in Burundi, $20 \mathrm{~m}$ deep. This distinct long-legged large species is found in deeper parts of the sublittoral zone in the northern end of the lake where the lake bed is muddy. This species has also been found in the stomachs of lake fish such as Chrysichthyes brachynema (Capart, 1952) and C. stappersi (Coulter, 1991).

Remarks. Platythelphusa tuberculata was originally described from a subadult female specimen because no males were known. The present diagnosis is based on an adult male specimen and includes the first account of the gonopods, male abdomen, sternum and chelipeds. This species can be distinguished from the other species in this genus by a large number of distinctive characters. These include the accentuated sculpture of the carapace regions, the strong spines on the lateral inferior margin of the merus of the cheliped, the large spine on the superior margin of the merus of the cheliped, the large spine on the external margin of the carpus of the cheliped, the highly arched and slim dactylus of the major cheliped of adult males, the elongated slim legs (the merus of P5 is much longer than the front width), the long, thin propodus of P5 and the very long, slim and curved dactyli of P2-P5 which have rows of very reduced spines.

Platythelphusa polita Capart, 1952

(figures $5,7 \mathrm{~h}, \mathrm{i}, 8 \mathrm{e}, \mathrm{o}, \mathrm{p}, 9 \mathrm{e}$ and $10 \mathrm{p}-\mathrm{s}$ )

Platythelphusa polita Capart, 1952: 455-457, figures $7 \mathrm{~d}, \mathrm{e}, \mathrm{g}$.

Potamonautes (Platythelphusa) polita: Coulter, 1991: 253-255, tables 9.XX, 9.XXI.

Material examined. Congo (formerly Zaire); Lake Tanganyika, Katibili Bay, $6 \mathrm{~m}$ deep, sand and shells (station 115); coll. A. Capart, 23 October 1952, $1 \mathrm{~m}$ ad., cw $13.6 \mathrm{~mm}, 1 \mathrm{f}$ ad., ovigerous, cw $12.2 \mathrm{~mm}$, syntypes (topotypes) (NHML 1952.10.23.34-35). Katibili Bay, 5m deep (station 2); coll. A. Capart, 23 October $1952,3 \mathrm{~m}$ ad., cw 13.2, 13.3, $14.2 \mathrm{~mm}, 1 \mathrm{~m}$ subad., cw $11.5 \mathrm{~mm}, 3 \mathrm{f}$ ad., cw 12.7 , $12.3,12.0 \mathrm{~mm}, 1$ f subad., cw $11.7 \mathrm{~mm}$, syntypes (NHML 1952.10.23.36-40). Tembwe Bay, $6 \mathrm{~m}$ deep, sandy and rocky lake bed (station 114); coll. A. Capart, 23 October $1952,1 \mathrm{~m}$ ad., cw $15.4 \mathrm{~mm}, 1 \mathrm{~m}$ subad., cw $8.6 \mathrm{~mm}, 6 \mathrm{f}$ ad., cw $11.611 .8,12.3,12.4$, 12.6, $12.7 \mathrm{~mm}, 1 \mathrm{f}$ subad., cw $10.1 \mathrm{~mm}$, hatchling, $\mathrm{cw} 2.7 \mathrm{~mm}$, syntypes (NHML 1952.10.23-29.33). Burundi; Lake Tanganyika, near Gitaza, $25 \mathrm{~km}$ south of Bujumbura, $2 \mathrm{~m}$ deep; coll. I. R. Bills, 1 June 1993, $2 \mathrm{~m}$ ad., cws $15.9,16.4 \mathrm{~mm}$, crabs inside empty Neothauma shells (CAW 10A). Five to $10 \mathrm{~m}$ deep, sand and scattered rocks; coll. I. R. Bills, 7 May 1993, $1 \mathrm{~m}$ ad., cw $12 . \mathrm{mm}, 1 \mathrm{f}$ ad., cw $12.8 \mathrm{~mm}$, 
crabs inside empty Neothauma shells (CAW 13A). Near Gitaza, $25 \mathrm{~km}$ south of Bujumbura; coll. I. R. Bills, 11 December 1992, 4 f ad., cws 13.0, 13.0, 14.7, $16.0 \mathrm{~mm}$, $3 \mathrm{~m}$ subad., cws 11.1, 11.4, $11.9 \mathrm{~mm}$, crabs inside empty Neothauma shells (CAW 87A). Near Gitaza, $25 \mathrm{~km}$ south of Bujumbura; 11 December 1992, $2 \mathrm{f}$ ad., cws 13.2, $15.9 \mathrm{~mm}$, crabs inside empty Neothauma shells (CAW 87B). Gitaza, 4m deep; coll. I. R. Bills, 1 June 1993, $4 \mathrm{~m}$ ad., cws $13.1,16.7,17.7,18.0 \mathrm{~mm}$, crabs inside empty Neothauma shells (CAW 88). Near Gitaza, $25 \mathrm{~km}$ south of Bujumbura, 11-18 m deep; coll. I. R. Bills, 1 June 1993, $7 \mathrm{~m}$ ad., cws 16.1, 16.3, 15.3, 16.7, 12.3, $12.4,11.5 \mathrm{~mm}, 7 \mathrm{f}$ ad., cws $12.2,13.4,13.5,13.9,13.9,13.9,14.2,15.9 \mathrm{~mm}, 6 \mathrm{f}$ subad., cws 9.6, 9.3, 12.2, 11.0, 11.0, 11.8 mm (CAW 89). Tanzania; Lake Tanganyika, South of Kabwe, Utinta Bay, 4-6m deep, on shell beds; coll. I. R. Bills, 16 May 1993,1 m juv., cw 7. mm (CAW 91).

Diagnosis. Carapace subhexagonal, rounded, medium wide ( $\mathrm{cw} / \mathrm{fw} 2.42$ ), little wider than long (cl/fw 2.05), high (ch/fw 1.07). Front deflexed slightly, edge smooth, each external corner marked by small, low tooth. Exorbital angle produced into broad low tooth, epibranchial tooth very small. Three teeth on anterolateral margin (anteriormost the tiny epibranchial tooth, other two large, subequal, directed forward). Sidewalls of carapace divided by epimeral sulcus into two parts, faint vertical sulcus can be detected under close examination. Suborbital margin lined by small granules, small tooth at medial end. Margins of inferior surface of merus of cheliped smooth; single large pointed distal tooth on medial inferior margin; superior margin of merus of P1 with short carinae. Inner margin of carpus of cheliped with two large subequal medial teeth, articular tooth (at point of articulation with propodus) low, blunt; outer margin of carpus smooth. Merus of P5 shorter than fw, distal tooth on superior margin of P2-P5 low. Propodus of P4 slim with smooth margins, propodus of P5 short, broad, margins of propodi of P5 flat, widened, smooth. Dactylus of P5 very short, only half as long as dactylus of P4. Dactyli of P2-P5 slim, curved, with rows of long spines. Terminal article of gonopod 1 directed sharply outward at $60^{\circ}$ angle to the vertical, stout, cone-shaped, tapering to pointed tip.

Description. See Capart (1952).

Size. The adult size range is from $\mathrm{cw} 12$ to $18 \mathrm{~mm}$ (table 2). The carapace dimensions are presented in figure 11; the carapace proportions are given in table 1 .

Distribution. Lake Tanganyika: Burundi, Tanzania and Zaire (table 3). For more localities see Capart (1952). Platythelphusa polita occurs in waters from 5 to $60 \mathrm{~m}$ deep, where the lake bottom is either sandy or rocky and there are shell beds. This species is sometimes found inside empty Neothauma shells.

Remarks. Platythelphusa polita is close to P. maculata but differs in the form of the articular tooth of the carpus of P1 (which is a sharp spine in P. maculata and a low, blunt tooth in $P$. polita), by the carapace height (which is medium high in $P$. polita and flat in $P$. maculata), and by the size of the epibranchial tooth (which is extremely small in $P$. polita and large and pointed in $P$. maculata).

There are clear differences between $P$. polita and $P$. armata. These include the body size at maturity (cw $12-13 \mathrm{~mm}$ in $P$. polita and $\mathrm{cw} 35-37 \mathrm{~mm}$ in $P$. armata), the articular tooth of the carpus of pereiopod 1 (low and blunt in $P$. polita and sharp and pointed in P. armata), and the terminal article of gonopod 1 (angled at $60^{\circ}$ to the vertical in $P$. polita and at $90^{\circ}$ to the vertical in $P$. armata). Platythelphusa polita is distinguished from juvenile $P$. armata by the relatively high carapace, by the dimorphism of the male chelipeds, by fewer spines on the anterolateral margin of the carapace, and by the distinctly smaller epibranchial tooth of $P$. polita. 
Differences between $P$. polita and $P$. echinata include the carapace height (medium height in $P$. polita and very flat in $P$. echinata), the inferior margins of P2-P5 (smooth in $P$. polita, very spiny in $P$. echinata), the margin of the merus of P1 (smooth in $P$. polita, very spiny in $P$. echinata), the frontal margin (smooth in $P$. polita, very spiny in $P$. echinata), and the sub-orbital margin (smooth in $P$. polita, very spiny in $P$. echinata).

Platythelphusa echinata Capart, 1952

(figures $6,7 \mathrm{j}, \mathrm{k}, 8 \mathrm{f}, \mathrm{q}, \mathrm{r}, 9 \mathrm{f}$ and $10 \mathrm{t}-\mathrm{w}$ )

Platythelphusa echinata Capart, 1952: 58-60, figures 7h, i, 9 .

Potamonautes (Platythelphusa) echinata Coulter, 1991: 253-255, tables 9.XX, 9.XXI.

Material examined. Tanzania; Lake Tanganyika, $10-15 \mathrm{~km}$ from Malagarazi river, 5-50 m deep, on a sandy lake bed (station 88); coll. A. Capart, 23 October $1952,4 \mathrm{~m}$ ad., cws $13.4,13.9,14.4,15.2 \mathrm{~mm}, 1 \mathrm{~m}$ subad., cw $12.6 \mathrm{~mm}, 5 \mathrm{f}$ ad., cw 13.3, 13.6, 13.9, 14.5, 14.8 mm, syntypes (NHML 1952.10.23.23-27). Burundi; Lake Tanganyika, at Magara (= Makara), $10-15 \mathrm{~m}$ deep, rocky lake bed; coll. I. R. Bills, 6 June 1993, $2 \mathrm{~m}$ ad., cws $18.8,19.1 \mathrm{~mm}, 7 \mathrm{~m}$ subad., cws 7.5, 8.2, 8.3, 9.5, 11.9, 13.3, $15.1 \mathrm{~mm}, 3 \mathrm{f}$ ad., cws 18.5, 20.2, $21.0 \mathrm{~mm}, 1 \mathrm{f}$ subad., cw $15.1 \mathrm{~mm}$ (CAW 11A).

Diagnosis. Carapace subhexagonal rounded, medium wide (cw/fw 2.44$)$, only little wider than long (cl/fw 2.03), very flat (ch/fw 0.76 ). Frontal margin with row of small granules, small blunt tooth at each external corner. Exorbital angle produced into small pointed tooth, epibranchial tooth large. Four teeth on anterolateral margin (anteriormost the large pointed epibranchial tooth, other three decreasing in size posteriorly), margin continuous with posterolateral margin. Suborbital margin lined by small granules, no small tooth at medial end. Lateral inferior margin of merus of cheliped smooth; large pointed tooth, several medium-sized teeth on medial inferior margin; superior margin with row of small granules. Inner margin of carpus of cheliped with two large subequal teeth close together, articular tooth (at point of articulation with propodus) large, pointed; outer margin of carpus with row of small granules. 'Coxa of P2-P5 with sharp spine on inferior medial margin. Merus of P5 as long as fw, sharp distal tooth on superior margin. Propodus of P4 long, propodus of P5 short, broad, posterior margin of propodus of P2 P5 lined by large pointed teeth. Dactyli of P2-P5 curved, rows of spines very long. Terminal article of gonopod 1 directed sharply outward at $90^{\circ}$ angle to the vertical, slim, cone-shaped, tapering to pointed tip.

Description. See Capart (1952).

Size. The adult size range is from $\mathrm{cw} 16$ to $21 \mathrm{~mm}$ (table 2). The carapace dimensions are presented in figure 11; the carapace proportions are given in table 1 .

Distribution. Lake Tanganyika: Burundi (table 3). For more localities see Capart (1952). This species is found in waters from 10 to $30 \mathrm{~m}$ deep, where the lake bed is sandy or rocky, and is sometimes found inside empty Neothauma shells.

Remarks. The two rows of short spines on the inferior border of the merus and propodus of P2-P5 distinguish $P$. echinata from all other species in this genus. In addition, the large spine on the coxae of P1-P5 of $P$. echinata distinguishes it from all other species in the genus, except $P$. tuberculata.

\section{Discussion}

Platythelphusa was first described from a female $P$. armata by A. Milne-Edwards (1887) who was initially inclined to assign it to the Grapsidae because of the rounded 
square-shaped carapace outline of $P$. armata. However, the fact that $P$. armata shows direct development and that the abdomen of adult females has a very wide telson convinced A. Milne-Edwards (1887) to group this species with the true freshwater crabs.

Rathbun (1904, 1905), Alcock (1910), and Bouvier (1917a,b, 1921) all assigned Platythelphusa to the Potamoninae. However, Colosi (1920) thought differently, and established the subfamily Platythelphusinae for the single genus (Platythelphusa) and the single species $(P$. armata). More recent authors (Capart, 1952; Bott, 1955; Balss, 1957; Coulter, 1991) did not accept Colosi's opinion and continued to group Platythelphusa with the African potamonautids. Recently, Sternberg and Cumberlidge (1998) and Cumberlidge (1999) carried out a preliminary cladistic analysis that indicated that the species of Platythelphusa belong to a distinctly separate clade from that of the African freshwater crabs of the Potamonautidae. Cumberlidge (1999) raised the subfamily Platythelphusinae Colosi, 1920 to family level and referred the six species of Platythelphusa to the Platythelphusidae, and this was supported by the study of Sternberg and Cumberlidge (1998).

Cumberlidge (1999) and Sternberg and Cumberlidge (1998) did not support Bott's (1955) assignation of Platythelphusa as a subgenus of Potamonautes and considered it unlikely that Platythelphusa was close to Potamonautes, and unlikely that these genera share a recent common ancestor. The present study broadly supports Capart's (1952) conclusions regarding the number of species in this genus, with the exception that $P$. conculata is recognized as a valid species and $P$. denticulata is considered here to be a junior synonym of $P$. conculata.

Key to the species of Platythelphusa

1a Frontal margin slightly deflexed, merus of P5 shorter than front width. Epibranchial tooth very small, only two large teeth on anterolateral margin behind exorbital angle tooth. . . . . . . . . . . . . . . . . . . P. polita

1b Frontal margin horizontal, not deflexed, merus of P5 greater than, or equal to, front width. Epibtanchial tooth large; three or more large teeth on anterolateral margin behind exorbital angle tooth

2a Lateral inferior margin of merus of cheliped with row of large spines, superior margin of merus of cheliped with large spine, coxa of cheliped with large spine on inferior side, dactylus of major cheliped of adult males highly arched, slim, walking legs (P2-P5) elongated, slim . . . . . . . . . . . . . . P. tuberculata

2b Lateral inferior margin of merus of cheliped smooth, superior margin of merus of cheliped lacking large spine; coxa of cheliped smooth; lacking spine, walking legs (P2-P5) short, broad

3a Terminal article of gonopod 1 angled outward between $45^{\circ}$ and $60^{\circ}$ to the vertical .

. . . . . . . . . . . . . . P. maculata

3 b Terminal article of gonopod 1 angled sideways at $90^{\circ}$ to the vertical . . . . . 4

4a Distal tooth on superior margin of merus of P2-P5 blunt, low, not pointed. Carapace of medium height (ch/fw approx. 1.07) . . . . . . . . . . . P. armata

$4 \mathrm{~b}$ Distal tooth on superior margin of merus of P2-P5 a large sharp spine. Carapace flat (ch/fw approx. $0.75-0.86)$. . . . . . . . . . . . . . . . . . 5

5a Outer margin of carpus of P1 with row of small sharp spines. Inferior margin of propodus of P2-P5 smooth . . . . . . . . . . . . . P. conculata

$5 \mathrm{~b}$ Outer margin of carpus of P1 smooth. Distinct rows of large spines on inferior margin of propodus of P2-P5 . . . . . . . . . . . . . . . . . . . . P. echinata 


\section{Acknowledgements}

We are grateful to F. C. de Moor of the Albany Museum, Grahamstown, South Africa for loaning the material. We are also very grateful to Paul F. Clark and Miranda Lowe (NHML), for loaning the type specimens used in this work. I especially thank artist Joanne Shelby for most of the illustrations used in this paper, and Denise Seubert, for assistance with the gazetteer. This work was supported in part by a faculty grant to one author (NC) from Northern Michigan University.

\section{References}

ALCOCK, A., 1910, On the classification of the Potamonidae. Records of the Indian Museum, $5,253-261$.

BALss, H., 1929, Über Ostafrikanische Potamonidae (Decapoda), mit Anhang: Potamoniden von Madagascar, Zoologischer Jahrbücher, Abteilung fur Systematik, 58, 339-358.

Balss, H., 1936, Beitrage zur Kenntnis der Potamidae (Süsswasserkrabben) des Kongogebeites, Revue du Zoologie et Botanie d'Afrique, 28, 65-204.

Balss, H., 1957, Decapoda, VIII: Systematik, in H. G. Bronn, Klassen und Ordnungen des Tierreichs, Band 5, Abteilung 1, 7(12), 1505-1672.

BEAdLE, L. C., 1981, The Inland Waters of Tropical Africa. An Introduction to Tropical Limnology (New York: Longman), pp. 1-475.

BILLS, I. R., 1996, Eco-ethology of shell-dwelling cichlids in Lake Tanganyika, unpublished MSc thesis, Rhodes University, Grahamstown, South Africa, pp. 1-153.

Botr, R., 1955, Die Süsswasserkrabben von Afrika (Crust., Decap.) und ihre Stammesgeschichte, Annales du Musée Royal du Congo Belge, (Tervuren, Belgique) C, Zoologie, 1(3, 3), 209-352.

BotT, R., 1970, Betrachtungen über die Entwicklungsgeschichte und Verbreitung der Süsswasser-Krabben nach der Sammlung des Naturhistorischen Museums in Genf/ Schweiz, Revue Suisse de Zoologie, 77(2), 24, 327-344.

Bouvier, E. L., 1917a, Sur la classification des Eupotamonea, crabes d'eau douce de la famille des Potamonidés, Comptes-rendus de l'Académie des Sciences (Paris), 165, 613-621.

Bouvier, E. L., 1917b, Sur la classification des Parapotamonea, crabes d'eau douce de la famille des Potamonidés, Comptes-rendus de l'Académie des Sciences (Paris), 165, 657-659.

Bouvier, E. L., 1921, Decapoda, in Voyage de Ch. Alluaud et R. Jeannel en Afrique orientale (1911-1912), Résultats scientifiques, Crustacés, III (Paris), 23-62.

Brichard, P., 1989, The Cichlids and all other Fishes of Lake Tanganyika (TFH Plaza, Neptune City, New Jersey: T. F. H. Publications), pp. 1-544.

CAPART, A., 1952, Exploration hydrobiologique du Lac Tanganyika (1946-1947), Results scientifiques-Crustaces, Decapodes, Brachyures, Instittu Royal des Sciences Naturelles, Belgique, III (3), 41-67.

ChACE, F. A., 1942, Scientific results of a fourth expedition to forested areas in east Africa. III: Decapod Crustacea, Bulletin of the Museum of Comparative Zoology, Harvard College, $91,185-233$.

Colosi, G., 1920, I Potamonidi conservati del R. Museo Zoologico di Torino. Bolletino dei Musei di Zoologia ed Anatomia comparata della R. Universita di Torino, 35(734), 1-39.

Coulter, G. W., 1991, Lake Tanganyika and its Life (Oxford: Oxford University Press), pp. $1-354$.

CUMBERLIDGE, N., 1986, Ventilation of the branchial chambers in the amphibious West African fresh-water crab Sudanonautes (Convexonautes) aubryi monodi (Balss, 1929) (Brachyura, Potamonautidae), Hydrobiologia, 134, 53-65.

CUMBerLidGe, N., 1991, The respiratory system of Globonautes macropus (Rathbun, 1898), a terrestrial fresh-water crab from Liberia (Gecarcinucoidea, Gecarcinucidae), Crustaceana, 61(1), 69-80.

CumberLIDGe, N., 1995, Redescription of Sudanonautes floweri (De Man, 1901) (Brachyura: Potamoidea: Potamonautidae) from Nigeria and Central Africa, Bulletin of the British Museum of Natural History (Zoology), London, 61(2), 111-119. 
Cumberlmge, N., 1999, The Freshwater Crabs of West Africa (Monograph, Faune et Flore Tropicale) (Paris: ORSTOM), in press.

Cumberlidge, N. and SACHS, R., 1991, Ecology, distribution, and growth in Globonautes macropus (Rathbun, 1898), a tree-living fresh-water crab from the rain forests of Liberia (Parathelphusoidea, Gecarcinucidae), Crustaceana, 61(1), 55-68.

Cunnington, W. A., 1899, On a new Brachyurous crustacean from Lake Tanganyika, Proceedings of the Zoological Society of London, 1899, 697-704.

Cunnington, W. A., 1907, Zoological results of the third Tanganyika expedition, conducted by Dr. W. A. Cunnington, 1904-1905, Report on the Brachyurous crustacea, Proceedings of the Zoological Society of London, 2, 258-276.

Cunnington, W. A., 1920, The fauna of the African Lakes: A study in comparative limnology with special reference to Lake Tanganyika, Proceedings of the Zoological Society of London, 3, 507-622.

GunNot, D., 1977, Propositions pour une nouvelle classification des Crustacés Décapodes Brachyoures, Comptes-rendus hebdomadaires des séances de l'Académie des Sciences (Paris), série D, 285, 1049-1052.

Hilgendorf, F., 1898, Die Land- und Süßwasser-Dekapoden Ostafrikas, Die Thierwelt Deutsch Ost-Afrikas, 4(7), 1-37.

MACLEAY, W. S., 1838, Brachyurous Decapod Crustacea. Illustrations of the zoology of South Africa 5; being a portion of the objects of natural history chiefly collected during an expedition into the interior of South Africa, under the direction of Dr. Andrew Smith, in the years 1834, 1835, and 1836; fitted out by "The Cape of Good Hope Association for Exploring Central Africa", in A. Smith, Illustrations of the Zoology of South Africa; Consisting Chiefly of figures and Descriptions of the Objects of Natural History Collected During an Expedition into the Interior of South Africa, in the Years 1834, 1835, and 1836; Fitted Out by "The Cape of Good Hope Association for Exploring Central Africa." (Invertebrates), 75 pp., pl. 1-4.

Milne-Edwards, A., 1887, Observations sur les crabes des eaux douces de l'Afrique, Annales des Sciences Naturelles, Zoologie, Paris, Série 5, 161-191.

Moore, J. E. S., 1903, The Tanganyika Problem (London: Hurst and Blackett).

Ortmann, A. E., 1896, Das System der Decapoden-Krebse, Zoologische Jahrbücher, Abteilung für Systematik, Geographie und Biologie de Thiere, 9, 409-453.

Rathbon, M. J., 1904, Les crabes d'eau douce (Potamonidae). Nouvelles Archives du Muséum d'Histoire naturelle (Paris), 6(4), 255-312.

Rathbun, M. J., 1905, Les crabes d'eau douce (Potamonidae), Nouvelles Archives du Muséum d'Histoire naturelle (Paris), 7(4), 159-322.

RATHBUN, M. J., 1933, Reports on the scientific results of an expedition to the southwestern Highlands of Tanganyika territory. 5, Crabs, Bulletin of the Museum of Comparative Zoology, Harvard College, 75(5), 251-260.

SмiтH, E. A., 1880, On the shells of Lake Tanganyika and the neighbourhood of Ujiji, central Africa. Proceedings of the Zoological Society of London, 1880, 344-352.

Sternberg von, R., Cumberlidge, N. and RodrigueZ, G., 1998, On the marine sister groups of the freshwater crabs (Crustacea: Brachyura), Journal of Zoological Systematics and Evolutionary Research, in press.

Sternaerg von, R. and CumberLidge, N., 1998, A cladistic analysis of the genus Platythelphusa A. Milne-Edwards, 1887 from Lake Tanganyika, East Africa (Decapoda: Potamoidea: Platythelphusidae) with comments on the phylogenetic position of the group, Journal of Natural History, in press.

West, K., Cohen, A. and Baron, M., 1991, Morphology and behaviour of crabs and gastropods from Lake Tanganyika, Africa: implications for lacustrine predator-prey coevolution, Evolution, 45, 589-607.

West, K. and COHEN, A., 1994, Predator-prey coevolution as a model for the unusual morphologies of the crabs and gastropods of Lake Tanganyika, in K. Martens et al. (eds), Speciation in ancient lakes. Archives Hydrobiologia, 44, 267-283. 